\title{
Ceramic-Polymer Composite Membranes for Water and Wastewater Treatment: Bridging the Big Gap between Ceramics and Polymers
}

\author{
Masashi Kotobuki, Qilin Gu (D, Lei Zhang and John Wang *
}

Department of Materials Science and Engineering, National University of Singapore, 9 Engineering Drive 1, Singapore 117575, Singapore; msemk@nus.edu.sg (M.K.); msegq@nus.edu.sg (Q.G.); msezlei@nus.edu.sg (L.Z.)

* Correspondence: msewangj@nus.edu.sg; Tel.: +65-6516-1268

Citation: Kotobuki, M.; Gu, Q.; Zhang, L.; Wang, J. Ceramic-Polymer Composite Membranes for Water and Wastewater Treatment: Bridging the Big Gap between Ceramics and Polymers. Molecules 2021, 26, 3331. https://doi.org/10.3390/molecules 26113331

Academic Editor: Xinhua Qi

Received: 4 May 2021

Accepted: 30 May 2021

Published: 1 June 2021

Publisher's Note: MDPI stays neutral with regard to jurisdictional claims in published maps and institutional affiliations.

Copyright: (c) 2021 by the authors. Licensee MDPI, Basel, Switzerland. This article is an open access article distributed under the terms and conditions of the Creative Commons Attribution (CC BY) license (https:/ / creativecommons.org/licenses/by/ $4.0 /)$.
Abstract: Clean water supply is an essential element for the entire sustainable human society, and the economic and technology development. Membrane filtration for water and wastewater treatments is the premier choice due to its high energy efficiency and effectiveness, where the separation is performed by passing water molecules through purposely tuned pores of membranes selectively without phase change and additional chemicals. Ceramics and polymers are two main candidate materials for membranes, where the majority has been made of polymeric materials, due to the low cost, easy processing, and tunability in pore configurations. In contrast, ceramic membranes have much better performance, extra-long service life, mechanical robustness, and high thermal and chemical stabilities, and they have also been applied in gas, petrochemical, food-beverage, and pharmaceutical industries, where most of polymeric membranes cannot perform properly. However, one of the main drawbacks of ceramic membranes is the high manufacturing cost, which is about three to five times higher than that of common polymeric types. To fill the large gap between the competing ceramic and polymeric membranes, one apparent solution is to develop a ceramic-polymer composite type. Indeed, the properly engineered ceramic-polymer composite membranes are able to integrate the advantages of both ceramic and polymeric materials together, providing improvement in membrane performance for efficient separation, raised life span and additional functionalities. In this overview, we first thoroughly examine three types of ceramic-polymer composite membranes, (i) ceramics in polymer membranes (nanocomposite membranes), (ii) thin film nanocomposite (TFN) membranes, and (iii) ceramic-supported polymer membranes. In the past decade, great progress has been made in improving the compatibility between ceramics and polymers, while the synergy between them has been among the main pursuits, especially in the development of the high performing nanocomposite membranes for water and wastewater treatment at lowered manufacturing cost. By looking into strategies to improve the compatibility among ceramic and polymeric components, we will conclude with briefing on the perspectives and challenges for the future development of the composite membranes.

Keywords: composite membrane; wastewater treatment; polymeric membrane; ceramic membrane; nanocomposite

\section{Introduction}

In pace with the ever rapid urbanization, industrialization, and population growth, the water shortage, especially clean water, has become one of the most critical problems globally. There is also a concurrent environmental issue, if and when untreated wastewater is released into rivers, lakes and seas directly, leading to surface and ground water contamination and depletion of the clean water supply [1]. Moreover, the ever rapid growing population in many regions has increased the demand for freshwater supply more recently. The United Nations has predicted that half of the countries worldwide will suffer from water shortage in the coming decade [2]. Therefore, water and wastewater 
treatments have been considered to be an essential and critical factor for sustainable human society development.

Several treatment processes can be used to treat wastewater and supply clean water. For example, membrane separation, adsorption, chemical precipitation, electrochemical treatment, ion-exchange, chlorination, and ozonation, etc., are among the commonly used techniques to remove hazardous materials for clean water supply [3]. Among them, membrane separation has been the most widely used, due to its high energy efficiency and relatively low cost. The membrane separation is performed by passing desired molecules through pores in membranes selectively based on their sizes, and the interaction between the molecules and the pores without phase change and additional chemicals [4]. The membrane systems are generally simple and consist of limited ancillary equipment. Due to the low cost and high efficiency, membrane technology has been widely employed for the production of various types of water [5], dialysis of blood and urine [6], ion separation in the electrochemical processes [7], and filtration of particulates from liquid suspensions [8].

The separation through membranes occurs via three different mechanisms: (i) sizeexclusion induced by the pores across the membrane, which allows passage of compounds smaller than the pore size, (ii) pore flow caused by the interaction between pore surface and passing molecules, which induces selective transportation of molecules with similar size to the pores, (iii) solution diffusion induced by the diffusion of molecules into the membrane, resulting in migration of the molecules across the membrane, which occurs exclusively in polymeric membranes. The fundamental properties that determine membrane performance are mainly the flux rate, selectivity, mechanical/chemical/thermal stabilities under operating conditions, fouling properties, and service durability. Since the membranes act as a barrier in the separation process, their surface properties, such as pore size, pore structure, surface roughness, and physicochemical properties largely influence the overall membrane performance. The roughness and hydrophilicity of the membranes influence the fouling behavior of the membrane significantly, while the mechanical/chemical/thermal stabilities determine the lifespan of the membranes [9].

Pore size, pore size distribution, morphology and surface properties of membranes primarily define membrane properties. For example, the pore size and its distribution mainly determine the selectivity, while properties of membrane materials influence permeability, fouling and selectivity. The overall thickness and pore shape in the membranes also affects the membrane flux. According to the pore size range, the membrane separation process for water purification and desalination can be classified into microfiltration (MF), ultrafiltration (UF), nanofiltration (NF) and reverse osmosis (RO) (Figure 1) [10]. In macroporous MF and mesoporous UF membranes, the principle phenomenon of solute rejection is the molecular sieving/size exclusion mechanism [11,12]. MF membranes typically reject those suspended particles, asbestos, and cellular materials, such as particles, bacteria, protozo, a and red blood cells. Contrarily, UF membranes have smaller pores and can reject smaller particles, microsolutes such as sugars and salts and macromolecules such as pyrogens, proteins, and viruses. NF membranes can reject low molecular weight-uncharged solutes by the size exclusion mechanism such as MF and UF membranes and charged molecules by a combination of the size exclusion mechanism, Donnan exclusion/equilibrium and dielectric exclusion (electrostatic interactions) $[13,14]$. They include most organic molecules, viruses, and salts. In particular, NF membranes can reject divalent ions and are often used for water softening [15]. In contrast to MF, UF, and NF membranes, RO membranes possess extremely small pores $(0.3-0.6 \mathrm{~nm})$, therefore, they can be considered to be non-porous. Molecular transport in RO membranes is governed by a solution diffusion mechanism in which solutes are dissolved into the membrane material and diffuse along with the concentration gradient [16]. The separation is performed in different solubility and diffusibility of the solutes. The most common application of $\mathrm{RO}$ membranes is the desalination of brackish groundwater and seawater $[17,18]$. 


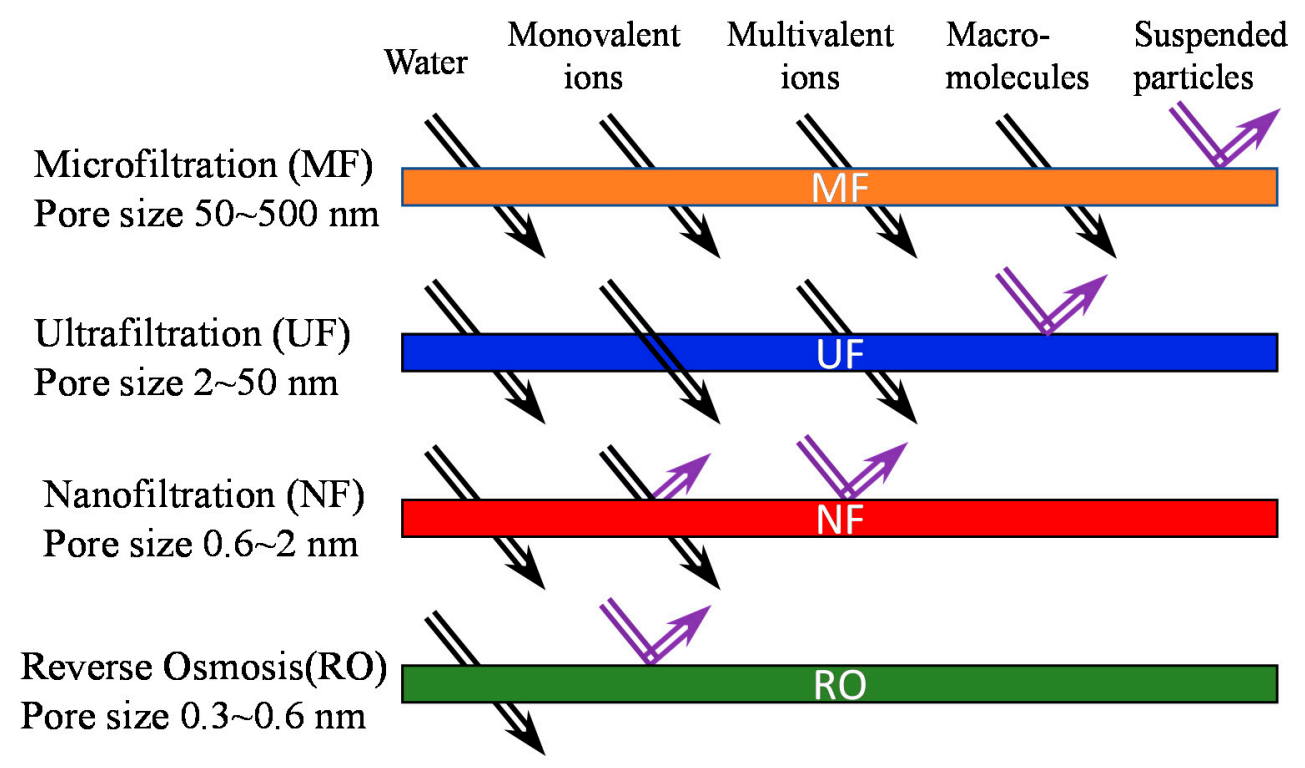

Figure 1. Pore size ranges of various membranes and the ability to reject particular foulants [19]. Reproduced with permission. Copyright in 2019, Elsevier.

Ceramics and polymers are the two main materials for various membranes. In particular, ceramic membranes have gained more attention recently, due to their superior performance, hydrophilicity, mechanical robustness, and high thermal and chemical stabilities, which allow at least double lifespan compared with the polymer membranes [20,21]. The common ceramic materials used in membrane applications are $\mathrm{Al}_{2} \mathrm{O}_{3}, \mathrm{TiO}_{2}, \mathrm{ZrO}_{2}$, $\mathrm{SiO}_{2}[19,22]$, and those containing a combination of them such as $\mathrm{Al}_{2} \mathrm{O}_{3}-\mathrm{ZrO}_{2}$ [23] and $\mathrm{TiO}_{2}-$ $\mathrm{SiO}_{2}$ [24], and various metal nanoparticles embedded in ceramics such as $\mathrm{Ag}-\mathrm{TiO}_{2}$ [25]. However, the relatively high production cost of the ceramic membranes is a restricting parameter in widening of their applications. Indeed, polymeric materials are still more widely used, although there is a steadily decrease in the overall market share. Polymer membranes have the merits of being low cost, tunable in porous structure, and ease in scale-up. Therefore, the polymer membranes have been dominantly employed for water, wastewater treatment, and desalination [1]. Among them, Poly-ethersulfone (PES) [26], Poly-sulfone (PSf) [27], poly-vinylidene fluoride (PVDF) [28,29], poly-vinylpyrrolidone (PVP) [30], poly-acrylonitrile (PAN) [31,32], poly-vinyl alcohol (PVA) [33,34], and polyvinyl acetate (PVAc) [35] are widely used as the polymeric membranes (Table 1). In addition to the poor life span, most of these polymeric membranes are inherently hydrophobic to certain extent, leading to low water flux, high fouling tendency, which often causes even shorter lifetime and higher operating cost.

One of the recent trends in membrane development is the ceramic-polymer composite membranes, which are able to integrate the advantages of ceramics and polymer materials, providing improvement in membrane performance for efficient separation and additional functionalities, while maintaining low cost. For example, the low flux and high fouling tendency due to hydrophobicity of polymer membranes could be mitigated by the addition of certain hydrophilic ceramic materials. Moreover, the material cost of ceramic-polymer composite membranes would be lower than that of ceramic membranes, since only a small amount of ceramic materials is included in the composite membranes. The concept of ceramic-polymer nanomembranes was reported in the 1970s. Ceramic fillers $\left(\mathrm{SiO}_{2}, \mathrm{Al}_{2} \mathrm{O}_{3}\right.$, etc.) were mixed into cellulose acetate (CA) membranes [36]. Since the 1980s, ceramicpolymer composite membranes have been applied for gas separation [37-39], where the ceramic fillers enhanced the membrane rigidity for better separation.

In this overview, we first examine the different types of inorganic-organic composite membranes and then recent progress of these ceramic-polymer composite membranes for water treatment, in three categories: (i) Ceramic fillers in polymer (nanocomposite) 
membranes, (ii) thin film nanocomposite (TFN) membranes, and (iii) Ceramic-supported polymer membranes (Figure 2). The technologies to improve the compatibility of the two components, which is the key to successfully fabrication of high performance and stable ceramic-polymer composite membranes, are discussed. Finally, the perspectives and challenges for the future development of the ceramic-polymer composite membranes will be visited.

Table 1. Structures of common polymer membranes.

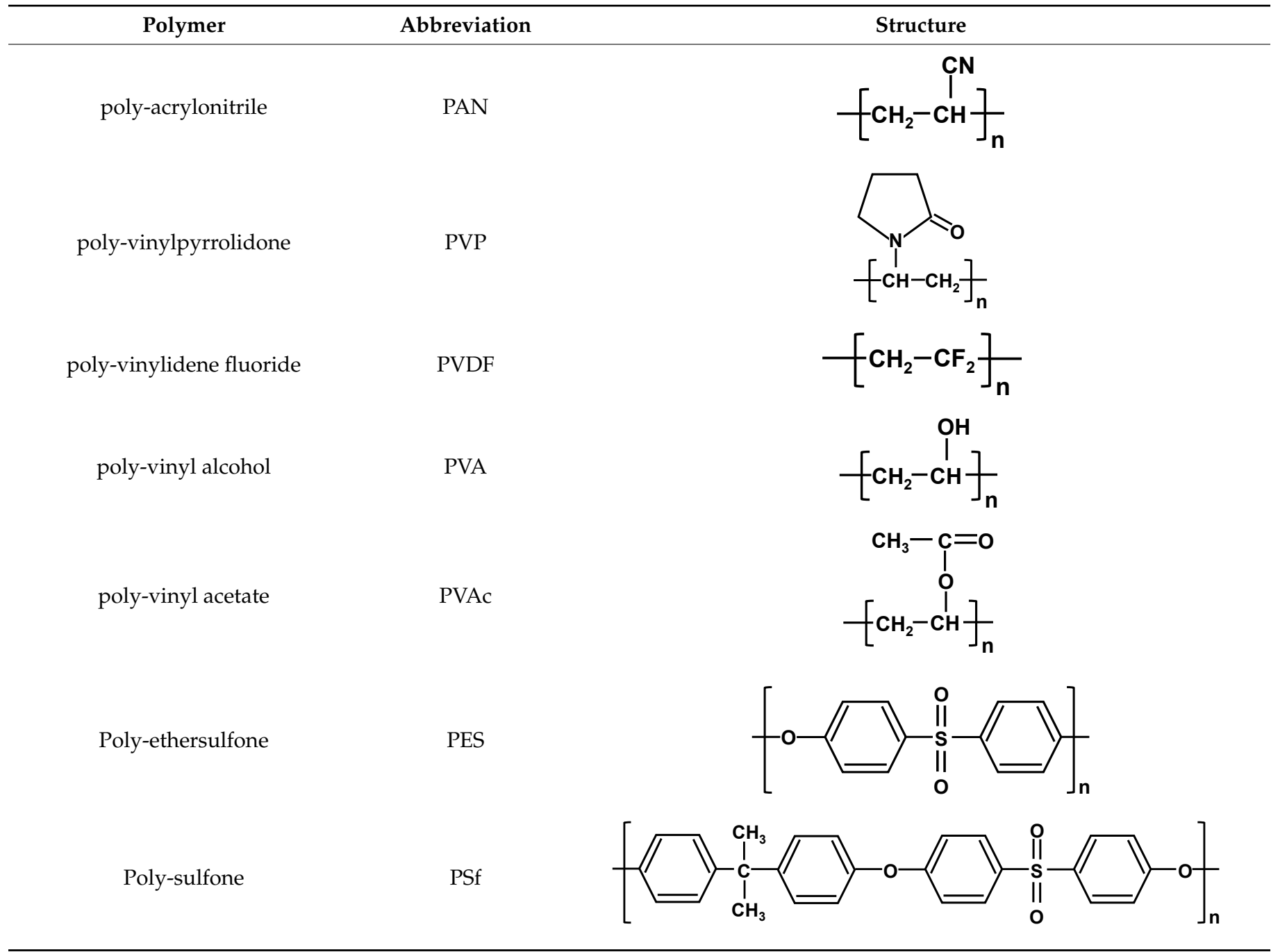

\section{Composite Membranes}

Composite membranes are commonly defined as polymer membranes, into which inorganic nanoparticles are incorporated, on which inorganic nanoparticles are deposited or which are supported by ceramic substrates as shown in Figure 2. There has been a steady rise in the published papers on the ceramic-polymer composite membranes, which have been employed in a large number of applications. More recently, new types of composite membranes are emerging, including those with MOFs (Metal-Organic Frameworks)/COFs (Covalent-Organic Frameworks) being incorporated/integrated. Moreover, there are also the composite-type membranes containing three/multi components, such as ceramic(different) ceramic-polymer, GO-CNT-polymer, carbon-ceramic-polymer MOF-carbonpolymer etc. 


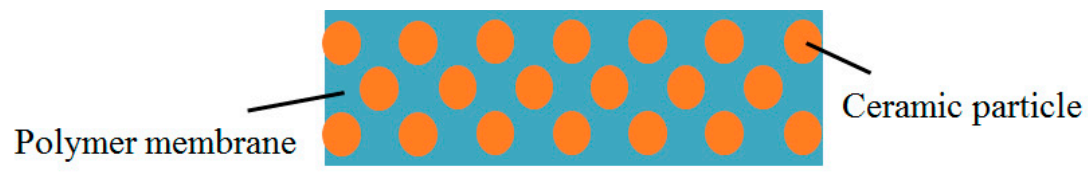

Nanocomposite membrane

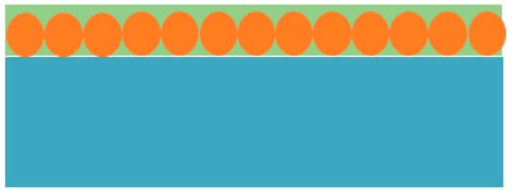

Thin-film nanocomposite (TFN) membranes

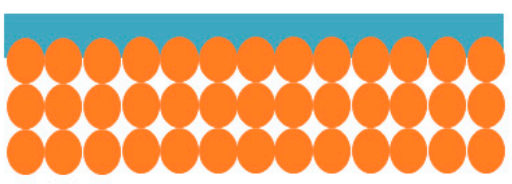

\section{Ceramic-supported polymer membrane}

Figure 2. Structures of ceramic-polymer composite membranes.

\subsection{Advantages of Inorganic-Polymer Composite Membranes}

1. Simultaneous enhancement of flux and rejection

In general, flux and rejection are of the trade-off relationship. When large pores are created in a membrane in order to improve the flux, this leads to reduce the rejection. Both enhancement of flux and rejection can be achieved by the composite membranes. For example, Nambikkattu et al. improved both glucose flux and rejection simultaneously by addition of $\mathrm{MgFe}_{2} \mathrm{O}_{4}$ on PSf membrane [40], where the addition of $\mathrm{MgFe}_{2} \mathrm{O}_{4}$ enhanced hydrophilicity of the membrane, but did not influence the pore structure, thus resulting in an improvement of both flux and rejection simultaneously.

\section{Addition of antibacterial and photocatalytic properties}

Certain metal nanoparticles, such as $\mathrm{Ag}$ and $\mathrm{Cu}$, are well-known for their antibacterial properties. Thus, by incorporation of $\mathrm{Ag}$ and $\mathrm{Cu}$ nanoparticles (NPs) into polymeric matrix, antibacterial properties can be added to the polymeric membranes. Indeed, high antibacterial behavior against E. coli, Bacillus Subtilis, etc. was reported in $\mathrm{Ag}$ and $\mathrm{Cu}$ NPs-containing polymeric membranes [41-43]. The superior antibacterial properties were also observed in GO-added PA membrane [44]. Likewise, photocatalytic property can be added into polymeric membranes by incorporation of $\mathrm{TiO}_{2}$ and $\mathrm{ZnO}$ [45-47]. Polymeric membrane themselves would not exhibit these antibacterial and photocatalytic properties.

3. Modification of morphology of polymeric membrane

The hydrophilicity of polymeric membrane can be enhanced by addition of certain hydrophilic inorganic NPs. Other properties can be also influenced by the addition of inorganic components into polymeric membranes. In particular, the morphology of polymeric components such as roughness, porosity, pore size, etc. can be strongly influenced, resulting in improvement of membrane performance [48-50].

4. Improvement of mechanical properties and thermal stability

The addition of certain inorganic component into polymeric membrane can improve the mechanical properties and thermal stability. For example, Poly-vinylidene chloride membrane with MCM-41 demonstrated higher tensile strength and then those of pristine polymeric membrane [51]. This phenomenon is more obvious in polymeric membrane 
on ceramic support [52]. Additionally, rGO addition to PDMS membrane increased the decomposition temperature of the polymer composite membrane [53].

\subsection{Disadvantages of Composite Membranes}

1. Compatibility between inorganic and organic components

One of the major issues with the nanocomposite membranes is the low compatibility between polymeric and inorganic components, which can cause aggregation of inorganic particles and separation of the two components, leading to poor performance, particularly in membrane stability. The stability of inorganic components in polymeric matrix has been performed by leaching test, exclusively in metal NPs-polymer membranes [54-56]. By contrast, in ceramic-polymer composite, the stability has been usually examined by the long-term antifouling test [57-59]. In the past decade, great progress has been made with improving the compatibility between both components, and a range of composite membranes with high stability have been prepared. Challenges in improvement of the compatibility between ceramic and polymeric components are summarized in Section 4.

2. Manufacturing cost

For polymeric membranes, phase inversion and casting have been widely used. These techniques can be directly applied for the nanocomposite-type membrane using polymer solution including inorganic NPs. In the case of TFN-type membrane, a polymeric support layer can be prepared first and the top inorganic layer is deposited on the support layer. In the case of ceramic-supported polymeric membrane, porous ceramic support is prepared first by sintering and then polymeric top layer is deposited by techniques such as dip coating, spin coating etc. These extra processes lead a degree of increase in membrane fabrication cost.

\section{Ceramic-Polymer Composite Membrane}

As shown in Figure 2, ceramic-polymer composite membranes can be divided into three groups. Nanocomposite membranes are composed of a polymeric membrane in which inorganic NPs are dispersed. This type of membranes has been most widely researched. The preparation for the nanocomposite membrane is mostly-based those well developed for polymer membranes, such as the phase inversion or casting of a polymer solution containing ceramic NPs. Either flat sheet or hollow fiber configurations can be obtained. The nanocomposite membrane has been used for both MF and UF processes. In the TFN membranes, a thin nanocomposite membrane is supported on a polymeric support, where ceramic NPs are located on the surface of the membrane and provide minimal influence on the intrinsic properties of polymeric substrate such as the pore structure. The surface properties of the resultant membrane are basically governed by ceramic NPs. The ceramicsupported polymer membranes consist of a thin polymer layer on a porous ceramic support. In contrast to the other two types of membranes, relatively dense and bulk ceramics, not ceramic NPs, are used in this type of membranes. The high chemical and thermal stability of ceramic supports restrict swelling of the thin polymer layer and improve flux and provide long membrane life. Highly tunable pore distribution and pore size of the polymeric surface layer influence the rejection properties of composite membranes. Coating on a polymer solution or in situ polymerization on a ceramic support has been employed to prepare the ceramic-support membranes. In all three types of membranes, not only the intrinsic properties of ceramic and polymeric components but also the interface properties between them influence the membrane performance significantly.

\subsection{Ceramics in Polymer (Nanocomposite) Membranes}

This type of membranes is composed of polymeric membranes in which ceramic NPs are dispersed in. Incorporation of the ceramic NPs into polymers could influence not only the hydrophilicity, pore size and distribution, surface roughness, but also can add new properties such as photocatalytic properties, antibacterial properties, etc. [60]. The 
fabrication of these membranes is mainly performed by casting and phase inversion (PI) using a polymer solution containing ceramic NPs [61].

Metal oxides such as $\mathrm{SiO}_{2}, \mathrm{Al}_{2} \mathrm{O}_{3}, \mathrm{TiO}_{2}, \mathrm{Fe}_{3} \mathrm{O}_{4}$ have been exclusively used as ceramic fillers for the nanocomposite membranes, where $\mathrm{TiO}_{2}$ is one of the most widely used ceramics in this type of membranes (Table 2). Additionally, natural minerals such as kaolin [62], cloisite [63] and montmorillonite [64] are studied to reduce material cost for inorganic components. The main advantages of $\mathrm{TiO}_{2}$ incorporation include the enhancement in hydrophilicity as well as antibacterial behavior by photocatalytic properties of $\mathrm{TiO}_{2}$ [65]. By the addition of $\mathrm{TiO}_{2}$, a decrease in contact angle and improvement of water flux have been reported by several groups. Additionally, UV-radiation enhances fouling resistance and antibacterial capability of $\mathrm{TiO}_{2}$-nanocomposite membranes due to the superhydrophilicity and photocatalysis of $\mathrm{TiO}_{2}$ under UV irradiation $[66,67]$. The UV irradiation also promote flux recovery of the $\mathrm{TiO}_{2}$-nanocomposite membrane [68].

Table 2. Summary of $\mathrm{TiO}_{2}$-based nanocomposite membranes.

\begin{tabular}{|c|c|c|c|c|}
\hline Ceramics & Polymer & Membrane & $\begin{array}{l}\text { Improved Properties by } \\
\text { Addition of Filler }\end{array}$ & Ref. \\
\hline $\mathrm{TiO}_{2}(25 \mathrm{~nm})$ & PVDF & Hollow fiber UF & Hydrophilicity & [68] \\
\hline $\mathrm{TiO}_{2}$ & PVDF & Hollow fiber UF & Hydrophilicity & [28] \\
\hline $\mathrm{TiO}_{2}(25 \mathrm{~nm})+$ dopamine & PVDF + PVP & UF & Hydrophilicity, Photocatalycity & [69] \\
\hline $\mathrm{TiO}_{2}(20 \mathrm{~nm})$ & PES & UF & $\begin{array}{l}\text { Hydrophilicity, antifouling } \\
\text { performance }\end{array}$ & [70] \\
\hline $\mathrm{TiO}_{2}(20 \mathrm{~nm})$ & PVDF & MF & antifouling performance & [71] \\
\hline $\mathrm{TiO}_{2}$ & PES & NF & Permeability, antifouling performance & [72] \\
\hline $\mathrm{TiO}_{2}(21 \mathrm{~nm})$ & PSf & Hollow fiber UF & antifouling performance & [73] \\
\hline $\mathrm{TiO}_{2}(62 \mathrm{~nm})$ & CA & - & Thermal stability, Water flux & [74] \\
\hline $\mathrm{TiO}_{2}(20 \mathrm{~nm})$ & PVDF-sulfonated-PES & Flat sheet UF & $\begin{array}{l}\text { Hydrophilicity, Antifouling, } \\
\text { photo-bactericidal effect }\end{array}$ & [75] \\
\hline $\mathrm{TiO}_{2}(20 \mathrm{~nm})$ & PVDF & UF & $\begin{array}{l}\text { Hydrophilicity, antifouling } \\
\text { performance }\end{array}$ & [76] \\
\hline $\mathrm{TiO}_{2}(20 \mathrm{~nm})$ & PVDF & UF & Hydrophilicity, Photocatalycity & [77] \\
\hline $\mathrm{TiO}_{2}$ & PAN & - & $\begin{array}{l}\text { Mechanical properties, Hydrophilicity, } \\
\text { Photocatalycity }\end{array}$ & [78] \\
\hline $\mathrm{TiO}_{2}$ & PVDF & - & Oil rejection, Water flux & [79] \\
\hline $\mathrm{TiO}_{2}$ & PSf & - & Dye removal & {$[80]$} \\
\hline
\end{tabular}

The enhancement in hydrophilicity by the addition of ceramic NPs has also been observed in other transition metal oxides, such as $\mathrm{SiO}_{2}$ [81-86], $\mathrm{Al}_{2} \mathrm{O}_{3}$ [87-90], $\mathrm{Fe}_{3} \mathrm{O}_{4}$ [91-95], and $\mathrm{ZrO}_{2}$ [96]. The influence of these ceramic fillers on the properties of polymeric membranes is dependent on the type and amount of fillers being added. For example, the addition of mesoporous silica into PES UF membrane does not affect the pore size significantly, but increases the level of porosity, resulting in an improved water flux (Table 3) [85]. Contrarily, the addition of $\mathrm{Fe}_{3} \mathrm{O}_{4}$ into PES membrane largely influences both pore size and the level of porosity (Table 4) [94]. The level of porosity increased by the $\mathrm{Fe}_{3} \mathrm{O}_{4}$ addition, while the pore size drastically decreased.

Table 3. Porosity, pore size and water flux of $\mathrm{SiO}_{2}$-contained PES membrane [85].

\begin{tabular}{|c|c|c|c|}
\hline Membrane & Porosity (\%) & Pore Size $(\mathrm{nm})$ & Water Flux $\left(\mathrm{L} \mathrm{m}^{-2} \mathrm{~h}^{-1}\right.$ at $\left.200 \mathrm{kPa}\right)$ \\
\hline PES & 69.2 & 12.9 & 122 \\
\hline $1 \mathrm{wt} \% \mathrm{SiO}_{2}-\mathrm{PES}$ & 74.8 & 13.7 & 145 \\
\hline $2 \mathrm{wt} \% \mathrm{SiO}_{2}-\mathrm{PES}$ & 75.9 & 14.6 & 180 \\
\hline $4 \mathrm{wt} \% \mathrm{SiO}_{2}-\mathrm{PES}$ & 74.9 & 12.8 & 137 \\
\hline
\end{tabular}


Table 4. Level of porosity, pore size and water flux of $\mathrm{Fe}_{3} \mathrm{O}_{4}$-contained PES membrane [94].

\begin{tabular}{cccc}
\hline Membrane & Porosity (\%) & Pore Size (nm) & Water Flux $\left(\mathbf{L ~ m}^{-\mathbf{2}} \mathbf{h}^{\mathbf{- 1}}\right.$ at $\left.\mathbf{2 0 0} \mathbf{~ k P a}\right)$ \\
\hline $\mathrm{PES}$ & 17 & 89.3 & 5 \\
$1 \mathrm{wt} \% \mathrm{Fe}_{3} \mathrm{O}_{4}$-PES & 33 & 40.1 & 6 \\
$5 \mathrm{w} \mathrm{t} \% \mathrm{Fe}_{3} \mathrm{O}_{4}$-PES & 44 & 3.9 & 12 \\
$10 \mathrm{wt} \% \mathrm{Fe}_{3} \mathrm{O}_{4}$-PES & 59 & 5.8 & 21 \\
\hline
\end{tabular}

Arsuaga et al. had compared the properties of $\mathrm{TiO}_{2}, \mathrm{Al}_{2} \mathrm{O}_{3}, \mathrm{ZrO}_{2}$-added PES UF membranes [96]. These ceramic fillers decreased the contact angle and enhance the level of porosity. The enhancement of water flux was in order of $\mathrm{Al}_{2} \mathrm{O}_{3}>\mathrm{TiO}_{2}>\mathrm{ZrO}_{2}$ (Table 5).

Table 5. Contact angle, level of porosity and water flux of $\mathrm{TiO}_{2}, \mathrm{Al}_{2} \mathrm{O}_{3}, \mathrm{ZrO}_{2}$-added PES membrane [96].

\begin{tabular}{cccc}
\hline Membrane & Contact Angle $\left(^{\circ}\right)$ & Porosity $(\mathbf{\%})$ & Water Flux $\left(\mathbf{L ~} \mathbf{~ m}^{-\mathbf{2}} \mathbf{h}^{-\mathbf{1}}\right.$ at $\left.\mathbf{3 0 0} \mathbf{~ k P a}\right)$ \\
\hline $\mathrm{PES}$ & 52.3 & 51.8 & 182 \\
$\mathrm{TiO}_{2}$-PES & 44.1 & 66.6 & 199 \\
$\mathrm{Al}_{2} \mathrm{O}_{3}$-PES & 37.8 & 62.1 & 209 \\
$\mathrm{ZrO}_{2}$-PES & 48.6 & 64.3 & 190 \\
\hline
\end{tabular}

The effects of ceramic fillers in polymer membranes are significantly influenced by the properties of base polymeric membranes [83]. Table 6 summarizes the properties of various $\mathrm{TiO}_{2}$-nanocomposite membranes. For example, in the $\mathrm{CA}$ (cellulose acetate)-based nanocomposite, the contact angle is slightly increased by the addition of $\mathrm{TiO}_{2}$, while a decrement in contact angle is observed in PES, PPESK (poly-phthalazine ether sulfone ketone), and PSf-based composites. The $\mathrm{TiO}_{2}$ addition impacts the level of porosity of PES, PPESK, and PSf membranes, although it does not affect the level of porosity of PVDF membrane significantly. The ceramic fillers must be chosen carefully depending on the properties being improved.

Table 6. Properties of various $\mathrm{TiO}_{2}$-added membranes reported.

\begin{tabular}{|c|c|c|c|}
\hline Membrane & Contact Angle $\left(^{\circ}\right)$ & Porosity (\%) & Ref. \\
\hline PES & 52.3 & 51.8 & [96] \\
\hline 0.4 wt. $\% \mathrm{TiO}_{2}$-PES & 44.1 & 66.6 & [96] \\
\hline PPESK & 50.7 & 80.5 & [97] \\
\hline 1 wt. $\% \mathrm{TiO}_{2}$-PPESK & 45.9 & 86.8 & [97] \\
\hline PSf & 70.1 & 63.4 & [98] \\
\hline 1 wt. $\% \mathrm{TiO}_{2}$-PSf & 52.0 & 81.0 & [98] \\
\hline CA & 69.3 & - & [99] \\
\hline 5 wt. $\% \mathrm{TiO}_{2}-\mathrm{CA}$ & 71.1 & - & [99] \\
\hline PVDF & - & 72.2 & [54] \\
\hline 1 wt. $\% \mathrm{TiO}_{2}-\mathrm{PVDF}$ & - & 73.9 & [54] \\
\hline
\end{tabular}

\subsection{Thin Film Nanocomposite (TFN) Membranes}

This type of membranes is composed of a thin nanocomposite membrane supported on polymer substrates. The concept of TFN membrane was first suggested in the 1970s, and it has been widely studied for desalination of seawater/brackish water, removal of heavy metals, organic micropollutants and pharmaceutically active compounds [61]. PSf has widely been used as a supporting layer while PA (polyamide) has been widely employed in the thin top layer. As inorganic compounds, (a) metal oxide NPs, (b) metal NPs and (c) carbon materials such as CNT and GO have been studied (Table 7). 
Table 7. Summary of surface nanocomposite membranes.

\begin{tabular}{|c|c|c|c|}
\hline Top Layer & Polymeric Support & Improved Properties & References \\
\hline $\mathrm{TiO}_{2}-\mathrm{PI}$ & PES & Salt rejection, Water flux & [100] \\
\hline Halloysite nanotube-PA & PSf & Antifouling performance, Water flux & [101] \\
\hline $\mathrm{TiO}_{2}-\mathrm{PA}$ & PSf & Antifouling performance & [102] \\
\hline $\mathrm{Fe}_{3} \mathrm{O}_{4} / \mathrm{ZnO}-\mathrm{PA}$ & PSf & Hydrophilicity, Water flux & {$[48]$} \\
\hline $\mathrm{SiO}_{2}-\mathrm{PA}$ & PSf & Hydrophilicity, Permeability, Salt rejection & [103] \\
\hline $\mathrm{Al}_{2} \mathrm{O}_{3}-\mathrm{PA}$ & PSf & Antifouling performance, Water flux & [104] \\
\hline $\mathrm{TiO}_{2} /$ Halloysite nanotube-PA & PSf & Antifouling performance, Recovery & [49] \\
\hline NaY-PA & PSf & Hydrophilicity, Permeability & {$[50]$} \\
\hline Mesoporous-silica-PA & PSf & Antifouling performance, Water flux & [105] \\
\hline ZnO-PDMS & PI & UV resistance, Superoleophilicity & [106] \\
\hline Clay-Chitosan & PVDF & Dye adsorption & [107] \\
\hline $\mathrm{TiO}_{2}$ & PS & Hydrophilicity, Water flix & [108] \\
\hline $\mathrm{TiO}_{2}$ & PAN & Water flux, Dye rejection & [109] \\
\hline $\mathrm{SiO}_{2}$ & PVDF & Dye rejection, Oil rejection & [110] \\
\hline $\mathrm{Bi}_{12} \mathrm{O}_{17} \mathrm{Cl}_{2}$ & CA & Dye removal & [111] \\
\hline $\mathrm{MoS}_{2}$ & PVDF & Salt rejection, Dye rejection & [112] \\
\hline $\mathrm{ZnWO}_{4}$ & PVDF & Dye rejection & [113] \\
\hline $\mathrm{TiO}_{2}$ & CA & Water flux, Dye rejection & [114] \\
\hline Au-Ag-PAA & PA & Antifouling and antibiofouling performance & [115] \\
\hline Arginine-Fe-PA & PES & Antifouling performance, Permeability & [116] \\
\hline CNT-PA & PSf & Antifouling performance, Salt rejection & [117] \\
\hline Amine-MWCNT-PA & PSf & Permeability, Salt rejection & [118] \\
\hline MWCNTs-PA & PSf & Antifouling performance, Water flux & [119] \\
\hline GO-PA & PAN & Antifouling performance, Hydrophilicity & [120] \\
\hline PVP-GO-PA & PSf & Salt rejection, Water flux & {$[121]$} \\
\hline $\mathrm{GO} / \mathrm{Fe}_{3} \mathrm{O}_{4}-\mathrm{PA}$ & PES & Water flux, Antifouling performance & [122] \\
\hline GO-PA & PSf & Water flux, Slat rejection & [123] \\
\hline GO-PA & PSf & Water flux, Hydrophilicity & [124] \\
\hline rGO-PDMS & PES & Thermal stability & [125] \\
\hline Quantum dot graphene-PA & PES & Anti-bacterial property, long-term stability & [126] \\
\hline Fullerenol $\left(\mathrm{C}_{60}(\mathrm{OH})_{n}\right)-\mathrm{PA}$ & PSf & Hydrophilicity, antifouling property & [127] \\
\hline
\end{tabular}

As in the nanocomposite membranes, $\mathrm{TiO}_{2}$ nanoparticles are among the most used in the thin top layer, and the water flux and antifouling properties are improved [49,100-102]. An optimum $\mathrm{TiO}_{2}$ loading in this type of membrane is reported as $0.05 \sim 0.1 \mathrm{wt} . \%$. This is much lower than that in $\mathrm{TiO}_{2}$-nanocomposite membranes, which is around $1 \mathrm{wt} . \%$. In the TFN configuration, $\mathrm{TiO}_{2}$ content can be drastically reduced. Exposing $\mathrm{TiO}_{2} \mathrm{NPs}$ on the surface significantly influences surface properties of membranes, resulting in reduction of $\mathrm{TiO}_{2}$ content. The TFN membrane could be fabricated at lower material cost compared to the nanocomposite membrane. In contrast, photocatalytic properties of $\mathrm{TiO}_{2}$ in the TFN membranes have not been widely reported. The optimum ceramic NP content is also in the same range (0.05-0.1 wt.\%) in the case of $\mathrm{SiO}_{2}$ NPs (Table 8) [103].

Table 8. Separation properties of PA/PSf membranes with various $\mathrm{SiO}_{2}$ contents [103].

\begin{tabular}{ccc}
\hline Membrane & Pure Water Permeability $\left(\mathbf{L ~ m}^{-\mathbf{2}} \mathbf{h}^{-\mathbf{1}} \mathbf{b a r}^{-\mathbf{1}}\right)$ & $\mathbf{N a C l}$ Rejection (\%) \\
\hline $\mathrm{PA} / \mathrm{PSf}$ & 2.94 & 72 \\
0.01 wt. $\% \mathrm{SiO}_{2}$-PA/PSf & 5.88 & 82 \\
0.05 wt. $\% \mathrm{SiO}_{2}$-PA/PSf & 9.52 & 89 \\
0.1 wt. $\% \mathrm{SiO}_{2}$-PA/PSf & 12.36 & 78 \\
\hline
\end{tabular}

Like the nanocomposite membranes, metal NPs $[115,116]$ and carbon materials $[117,118,120-122,124-139]$ have been studies as additives for the TFN membranes. In particular, the unique properties of carbon materials (CNT, GO, rGO, etc.) and their derivatives influence membrane properties drastically even with small amounts of addition. 


\subsection{Ceramic-Supported Polymer Membranes}

This type of membrane is composed of a thin polymeric film (selective layer, active layer) supported on a ceramic porous substrate (Figure 3, [140]). The ceramic substrates provide the superior chemical, mechanical and thermal stabilities as well as negligible transport resistance and defines the external shape of the membrane [44]. The ceramic-supported polymer composites have attracted much attention for their significant performance in UF [141], pervaporation [44,133-147], gas separation [148], etc. The thin polymeric layer, which can consist of one or more intermediate layers, is prepared by processes, such as interfacial polymerization, dip coating, etc. The level of air humidity during dip coating, drying process and polymer solution affected quality of top thin layer significantly $[148,149]$.

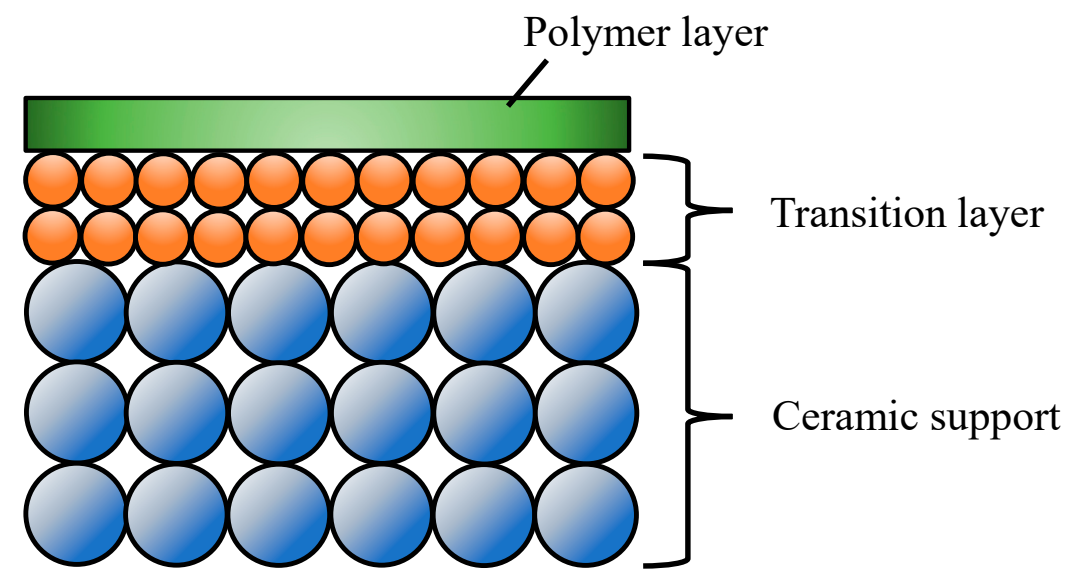

Figure 3. Structure of the ceramic-supported polymer composites.

Table 9 summarizes the ceramic-supported polymer nanocomposite membranes reported. For the ceramic substrates, $\mathrm{Al}_{2} \mathrm{O}_{3}, \mathrm{SiO}_{2}, \mathrm{TiO}_{2}$, and $\mathrm{ZrO}_{2}$ have been extensively used in forms of tubular, monolith, hollow fiber, and flat sheet. Additionally, natural minerals such as clay and kaolin have been applied to reduce the cost of ceramic substrates. Several types of polymeric thin films such as hydrophilic PA, PVA, PVP, PVAc, Chitosan, and hydrophobic polydimethylsiloxane (PDMS) have been employed for the thin top layer.

Table 9. Summary of the ceramic-supported polymer membranes.

\begin{tabular}{|c|c|c|c|}
\hline Polymer Thin Film & Ceramic Support & Improved Properties & References \\
\hline PDMS & $\mathrm{Al}_{2} \mathrm{O}_{3}$ hollow fiber & Butanol/water separation factor, long-term stability & [150] \\
\hline PA & $\mathrm{Al}_{2} \mathrm{O}_{3}$ tubular UF membrane & Dye rejection, methanol permeability & [151] \\
\hline PA & $\mathrm{Al}_{2} \mathrm{O}_{3}$ tubular & Salt rejection, water permeability & [152] \\
\hline PDMS & $\mathrm{ZrO}_{2} / \mathrm{Al}_{2} \mathrm{O}_{3}$ & Sulfur removal efficiency & [153] \\
\hline PVA & Fumed silica & Water selectivity, Pervaporation separation index & [52] \\
\hline Melamine-terephthaldehyde & $\mathrm{Al}_{2} \mathrm{O}_{3}$ & n-heptane permeability, dye rejection & [154] \\
\hline $\begin{array}{l}\text { PDADMAC/poly(sodium 4-styrene } \\
\text { sulfonate }\end{array}$ & $\mathrm{Al}_{2} \mathrm{O}_{3}$ monolith & Stability for backwashing, reusable ceramic support & [155] \\
\hline PA & $\mathrm{Al}_{2} \mathrm{O}_{3}$ hollow fiber & Water flux & [156] \\
\hline $\begin{array}{c}\text { Poly (maleic } \\
\text { anhydride-alt-1-alkenes) }\end{array}$ & $\gamma-\mathrm{Al}_{2} \mathrm{O}_{3} \mathrm{NF}$ membrane & Dye rejection, permeability & [157] \\
\hline Sulfonated polybenzimidazole & $\mathrm{TiO}_{2}, \mathrm{TiO}_{2} / \mathrm{ZrO}_{2}$ tubular & Mechanical ruggedness, flux & [148] \\
\hline PDMS & $\beta$-sialon & Long-term stability, recovery ability & [158] \\
\hline PDMS & $\mathrm{ZrO}_{2} / \mathrm{Al}_{2} \mathrm{O}_{3}$ tubular & High flux, recovery ability & [159] \\
\hline PA & $\mathrm{Al}_{2} \mathrm{O}_{3}$ & High $\mathrm{H}_{2} / \mathrm{CO}_{2}$ selectivity & [160] \\
\hline PVP & $\mathrm{ZrO}_{2}$ & Oil rejection, anti-fouling performance & [161] \\
\hline Chitosan & Clay+Kaolin & Rejection of mercury and arsenic, cost of membrane & [162] \\
\hline PDMS (polydimethylsiloxane) & $\mathrm{ZrO}_{2} / \mathrm{Al}_{2} \mathrm{O}_{3}$ tubular & High flux, Membrane stability & [163] \\
\hline PVAc, PVP & $\mathrm{Al}_{2} \mathrm{O}_{3}$ tubular & Separation factor & [164] \\
\hline PVAc & $\mathrm{SiO}_{2}$ tubular & Water flux & [165] \\
\hline PDMS & $\gamma-\mathrm{Al}_{2} \mathrm{O}_{3}$ & IPA selectivity & [166] \\
\hline PVA & $\mathrm{ZrO}_{2} / \mathrm{Al}_{2} \mathrm{O}_{3}$ tubular & Water permeability, Selectivity of water to ethyl acetate & [167] \\
\hline PSf-PEI & Flat Pozzolan & Water permeability, Dye rejection & [168] \\
\hline Sulfonated polybenzimidazole & $\mathrm{TiO}_{2} / \mathrm{ZrO}_{2}$ tubular & Flux, Pervaporation stability & [149] \\
\hline
\end{tabular}


The benefits offered by the ceramic-supported polymer membranes are mainly in high flux and long-term stability. For example, PDMS/ $\mathrm{Al}_{2} \mathrm{O}_{3}-\mathrm{ZrO}_{2}$ nanocomposite membrane shows about two times higher pervaporation flux of ethanol/water than that of the PDMS/Blend cellose acetate (BCA) membrane [163] (Figure 4). Additionally, the separation factor decreased with temperature monotonically in the PDMS/BCA membrane, while the peak of separation factor was shown at $50{ }^{\circ} \mathrm{C}$ in the PMDS $/ \mathrm{Al}_{2} \mathrm{O}_{3}$.
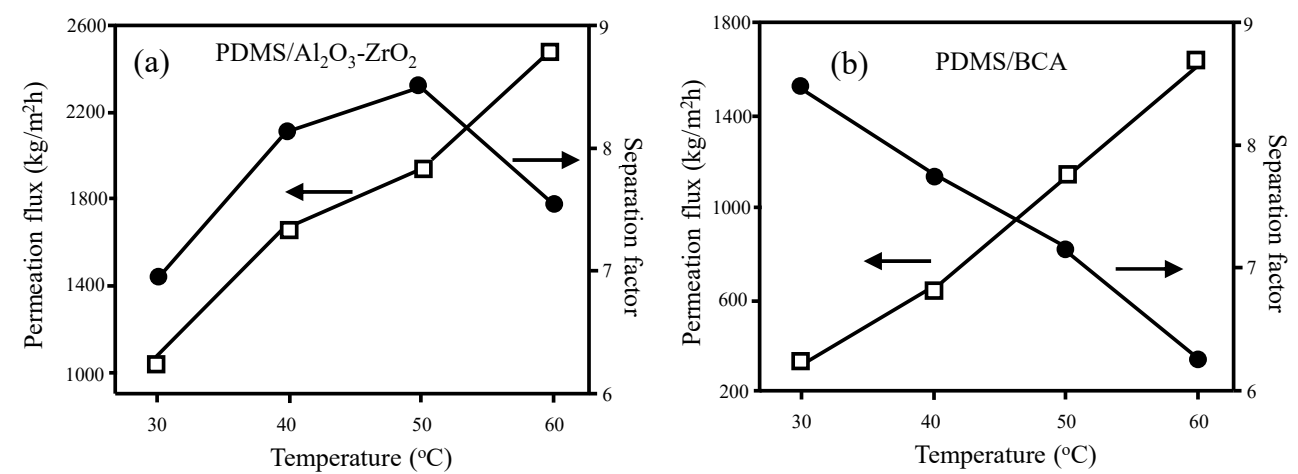

Figure 4. A comparison of pervaporation performance between (a) $\mathrm{PDMS} / \mathrm{Al}_{2} \mathrm{O}_{3}-\mathrm{ZrO}_{2}$ and (b) PDMS/BCA membranes [163]. Reproduced with permission. Copyright in 2011, Elsevier.

Additionally, their superior long-term stability are reported by several research groups $[148,150,159,163]$, where it is considered to be arising from the high structural, thermal, and chemical stabilities of ceramic supports in operating condition. In the polymersupported membranes, swelling of the polymeric support in the operation could damage the thin top layer, resulting in poor stability of the polymer-supported membranes. The swelling tendency is more prominent at high temperatures. Therefore, most of the commercial PA membranes with polymer support cannot be used above $50{ }^{\circ} \mathrm{C}$. Contrarily, PA supported on $\mathrm{Al}_{2} \mathrm{O}_{3}$ tubular membrane demonstrated stable rejection and permeation of $\mathrm{MgCl}_{2}$ at $70{ }^{\circ} \mathrm{C}$, due to the high stability of $\mathrm{Al}_{2} \mathrm{O}_{3}$ support which could stabilize the PA top layer [152].

It must be noted that the swelling process is different between the polymer-supported and ceramic-supported polymer membranes (Figure 5) [163]. In the polymer support, top and support layers are swollen in a parallel direction together (Figure 5a). The swelling influences pore structure and membrane performance. On the contrary, only the top layer can be swollen in the ceramic-support membranes (Figure 5b). The ceramic support maintains its pore structure and can suppress the swelling of top polymeric layer. Therefore, influence of the swelling is reduced in the polymer-supported membranes. This would be one of the reasons behind the superior performance of the ceramic-supported composite polymer membranes.

Ceramic-supported polymer composite membranes can recover their performance completely by back washing after fouling [158]. For example, PDMS/ $\beta$-Sialon membrane is fouled by the crystallization of $\mathrm{NaCl}$. After the membrane is scoured and dried to remove the crystallized $\mathrm{NaCl}$ on the surface, the flux could be completely recovered. Interestingly, for example, Menne et al. reported a reusable $\mathrm{Al}_{2} \mathrm{O}_{3}$ monolith support for PDADMAC/PSS (poly(sodium 4-styrene sulfonate)) film [157]. After fouling, the top PDADMAC/PSS layer is removed by sodium hypochlorite $(\mathrm{NaOCl})$ treatment. Then, a new top layer is built by the coating on the same $\mathrm{Al}_{2} \mathrm{O}_{3}$ monolith. Pure water permeability does not change by the removal and rebuilding of the top layer. This reusable ceramic support is expected to reduce material and production costs drastically.

By properly matching the properties between the ceramic support and a polymeric top layer, the ceramic-supported polymer composite membranes can feature high permeability. Additionally, the confinement in swelling of the polymeric top layer by a stable ceramic support provides long-term stability and allows high temperature operation. However, 
further research would be required to optimize the polymer-ceramic interface, in order to tailor the high performance of the ceramic-supported polymer composite membranes.

(a) Polymer support

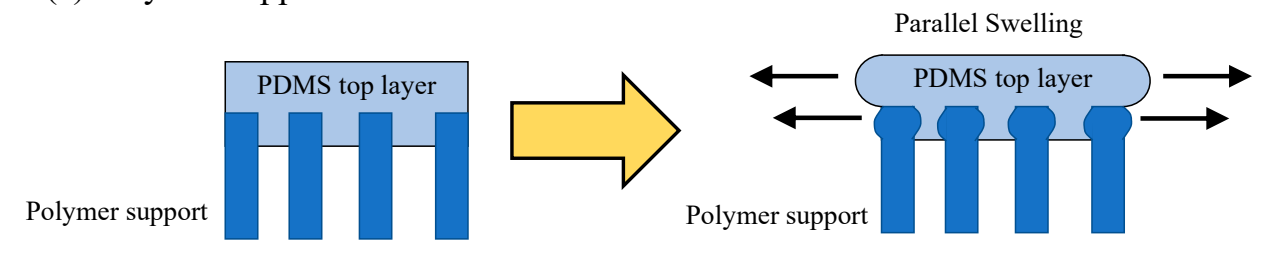

(b) Ceramic support
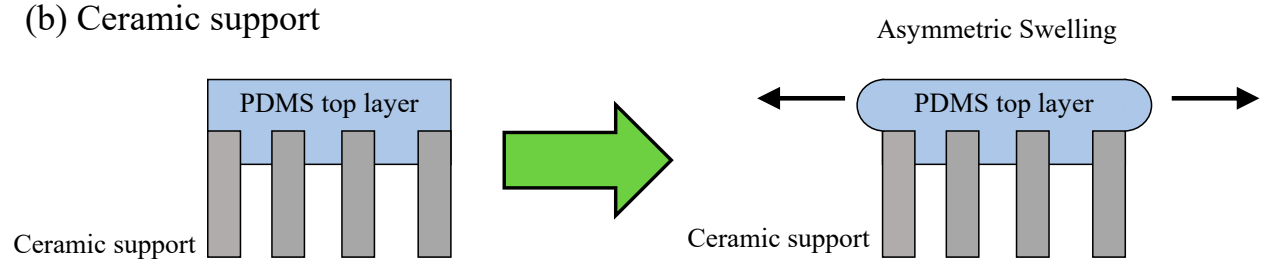

Figure 5. Swelling in (a) polymer-supported PDMS top layer and (b) ceramic-supported PDMS top layer [163]. Reproduced with permission. Copyright in 2011, Elsevier.

\section{Strategies to Fabricate Ceramic-Polymer Composite Membranes}

One of the challenges in fabrication of ceramic-polymer composite membranes is the incompatibility of the ceramic-polymer interface. According to the basic thermodynamic principles, the poor interfacial compatibility between ceramic and polymeric components would lead to separation and severe aggregation of each component, leaching out of ceramic nanoparticles, reduction in mechanical strength of the membranes, degradation in pore structure, change in hydrophilicity, and decrease in the stability of the composite membranes. In particular, some of the incorporated ceramic particles are usually highly polarized because of abundant polar moieties on their surfaces, while some commercial polymer membranes, such as PE and PP have a nonpolar nature. To address these issues, modification of both components is widely conducted to improve the compatibility of the ceramic-polymer interfaces. By an appropriate modification, the undesired differences between the ceramic particles and polymer matrix can be reduced. Surface modification can also improve membrane performance, such as increase in flux and fouling resistance $[167,168]$. The type of modifications is dependent on the membrane structure. In the nanocomposite membranes, ceramic surface and/or whole polymeric components can be tailored, while in the TFN membranes, mainly the surface modification of polymeric support is performed. Herein, some strategies to improve the compatibility between ceramic and polymeric components are described.

\subsection{Modification of Ceramic Nanoparticles}

In this strategy, ceramic NPs are modified with certain functional moieties for better compatibility with polymeric matrix. Intrinsically, cationic transition metals, such as $\mathrm{Ti}^{4+}$ in $\mathrm{TiO}_{2}$, can bond to the oxygen-containing functional groups such as $\mathrm{COOH}$ and $\mathrm{SO}_{2} \mathrm{OH}$ in the polymer matrix through coordination, stabilizing ceramic NPs in the polymer matrix [169]. However, in order to further improve the stability of the ceramic-polymer interface, the modification of ceramic NPs has been studied. For modifications of ceramic NPs, there are mainly three strategies, (1) surface modification, (2) surface functionalization, and (3) organic grafting on the particle surfaces.

\subsubsection{Surface Modification}

Hydroxyl groups on the surface of ceramic NPs can form hydrogen bonds with carboxyl groups, amino groups, hydroxyl groups, etc. in the polymeric matrix, resulting in stabilization of the NPs (Figure 6) [170]. Wang et al. applied a hydrothermal treatment to grow gibbsite $\left(\mathrm{Al}(\mathrm{OH})_{3}\right)$ on the surface of $\gamma-\mathrm{Al}_{2} \mathrm{O}_{3} \mathrm{NPs}$ and then added them into the 
PVDF membrane [171]. The gibbsite can form hydrogen bonds with fluoride atoms in the PVDF membrane. The gibbsite $/ \gamma-\mathrm{Al}_{2} \mathrm{O}_{3}$ NPs were stable for at least two days in dead-end filtration of MilliQ water at the flux of $5 \times 10^{-6}$ to $2.5 \times 10^{-5} \mathrm{~m} \mathrm{~s}^{-1}$. In addition, bio-fouling by E. coli could be greatly reduced. The stabilization of ceramic NPs in the polymeric matrix by the interaction between surface hydroxyl group on the ceramic NPs and functional groups in the polymeric matrix was also observed in $\mathrm{MnO}_{2}$ [172], $\mathrm{ZnO}$, and $\mathrm{ZrO}_{2}[173]$ as well.

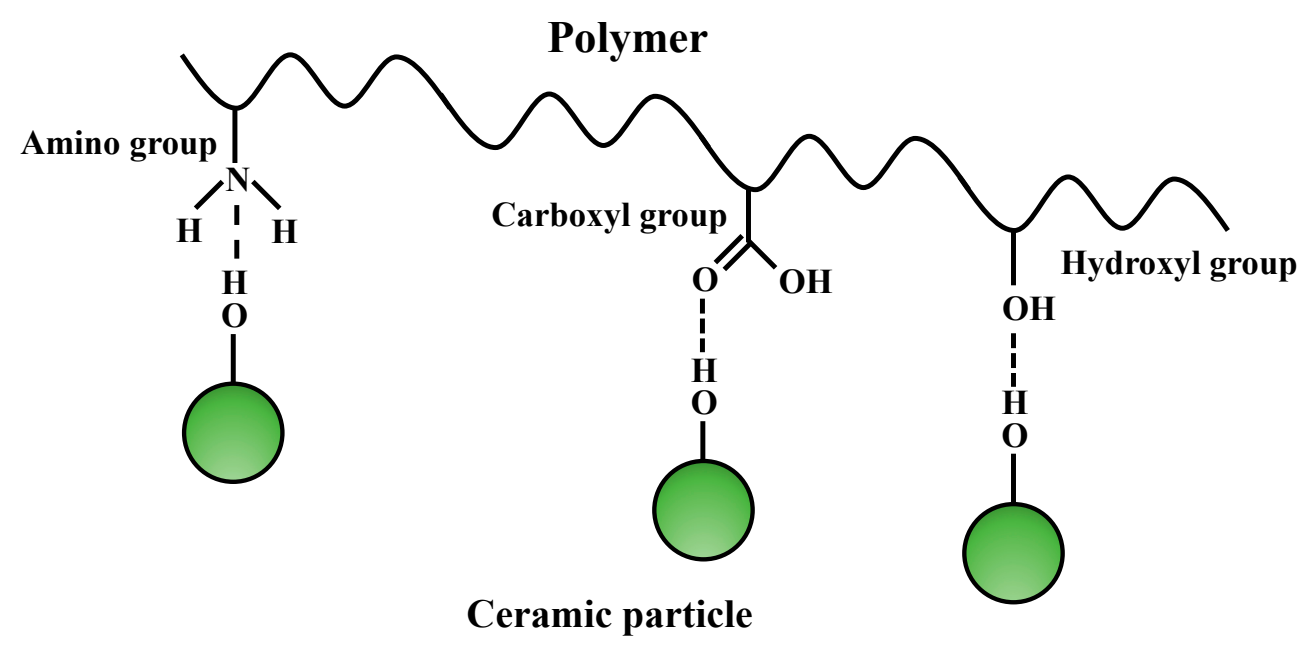

Figure 6. Illustration of the interfacial hydrogen bonds between hydroxyl group on the ceramic particles and functional groups in the polymeric matrix.

Surface sulfonation of inorganic particles has been also performed because the surface sulfonate group can react with the amide group in the polymetric matrix, leading to a high stability of the nanocomposite membrane [174]. For example, Sun et al. incorporated 3-mercapto-propyltrimethoxysilane-modified H-ZSM-5 zeolite into a chitosan membrane [175]. The $\mathrm{SO}_{3} \mathrm{H}$ group could be easily grafted on the surface of H-ZSM-5 and interacted with $\mathrm{NH}_{3}{ }^{+}$group in the chitosan membrane. By the interaction, not only leaching of ceramic NPs, but also the creation of nonselective voids at the interface between H-ZSM-5 and chitosan membrane could be suppressed, resulting in a high separation factor of 274.46 in the pervaporative dehydration of aqueous ethanol solution.

Additionally, the surface $\mathrm{SO}_{3} \mathrm{H}$ group on ceramic NPs can increase the negative charge of the nanocomposite membrane and enhance protein rejection due to electrostatic repulsion with negatively charged proteins. For example, sulfonated- $\mathrm{TiO}_{2}\left(\mathrm{~S}-\mathrm{TiO}_{2}\right)$ composited with PES UF membrane showed a higher bovine serum albumin (BSA) rejection as well as the level of porosity and hydrophilicity than those of pristine PES and non-sulfonated $\mathrm{TiO}_{2}$ composite membranes (Table 10) [176].

Table 10. Selected properties of PES, non-sulfonated $\mathrm{TiO}_{2} / \mathrm{PES}$ and $\mathrm{S}-\mathrm{TiO}_{2} / \mathrm{PES}$ membranes.

\begin{tabular}{cccc}
\hline Membrane & Porosity (\%) & Contact Angle ( $\left.{ }^{\circ}\right)$ & BSA Rejection (\%) \\
\hline PES & 68.4 & 75 & 88 \\
Non-sulfonated $\mathrm{TiO}_{2} / \mathrm{PES}$ & 77.3 & 60 & 92 \\
$\mathrm{~S}^{-\mathrm{TiO}_{2}} / \mathrm{PES}$ & 87.6 & 49.2 & 99 \\
\hline
\end{tabular}

The surface modification of ceramic NPs can provide not only an improvement in compatibility with polymeric matrixes but also influences on surface charge and pore structure of polymeric matrixes, resulting in better performance of the composite membranes. However, the relationship between the modification and influence on the pore structure is still unclear in several cases. 


\subsubsection{Surface Functionalization on Ceramic Nanoparticles}

Surface functionalization by in situ generation/growth of an inorganic component is also an effective approach to reduce the agglomeration and provide additional functionality for ceramic particles in polymer matrix [177]. For example, Zhang et al. coated $\mathrm{SiO}_{2}$ on $\mathrm{Fe}_{3} \mathrm{O}_{4}$ particle by the hydrolysis of tetraethyl orthosilicate [178], where the surface hydrated $\mathrm{SiO}_{2}$ layer prevented the aggregation of $\mathrm{Fe}_{3} \mathrm{O}_{4}$ NPs in PES polymer matrix and interacted with oxygen atom in the PES matrix. The membrane could be operated for $168 \mathrm{~h}$, continuously, in which the effect of coating of hydrated $\mathrm{SiO}_{2}$ is similar to surface hydration of ceramic NPs. However, hydrophilic $\mathrm{SiO}_{2}$ possesses more hydroxyl groups on the surface, giving rise to a higher stability in the polymeric matrix compared with direct surface modification of $\mathrm{Fe}_{3} \mathrm{O}_{4} \mathrm{NPs}$. Same strategy is applied for $\mathrm{ZrO}_{2}$-coated $\mathrm{SnO}_{2}$ [179], MCM-41-coated $\mathrm{SrCo}_{x} \mathrm{Cu}_{1-\mathrm{x}} \mathrm{O}_{3-\lambda}$ [180], and $\mathrm{TiO}_{2}$-coated hollysite nanotube [181].

The surface functionalization can change the stability of ceramic NPs in the polymeric matrix drastically compared with the surface modification. The functionalization is not limited to oxides and hydroxides. Recently, superior performance of CuS-coated $\mathrm{CuO}$ in PVDF was reported [182]. The superior performance could be observed in $60 \mathrm{~min}$. Although long-term stabilization must be examined, the surface functionalization by other compounds such as sulfide and phosphide is a new research area.

\subsubsection{Organic Grafting}

Polymeric matrixes are highly compatible with polymer components. The introduction of the grafted polymer chain on ceramic NPs shall increase the stability of the NPs in the polymeric matrix and suppresses aggregation of ceramic particles (Figure 7). For example, a hydrophilic polymer, poly (2-hydro-xyethyl methacrylate) (p(HEMA), was grafted on $\mathrm{TiO}_{2}$ nanoparticles. The surface $\mathrm{p}(\mathrm{HEMA})$ group helps improve the dispersibility of $\mathrm{TiO}_{2}$ nanoparticles in PSf flat UF membrane [183]. Compared to unmodified $\mathrm{TiO}_{2}$, the $\mathrm{p}(\mathrm{HEMA})$ grafted $\mathrm{TiO}_{2}$ enhances hydrophilicity and pure water flux and reduces BSA UF resistances. Similar research on polymer grafting was performed using various polymer including zwitter ionic polymers (Table 11). In all these studies, aggregation of inorganic NPs is suppressed and hydrophilicity and water flux of the composite membranes are enhanced.

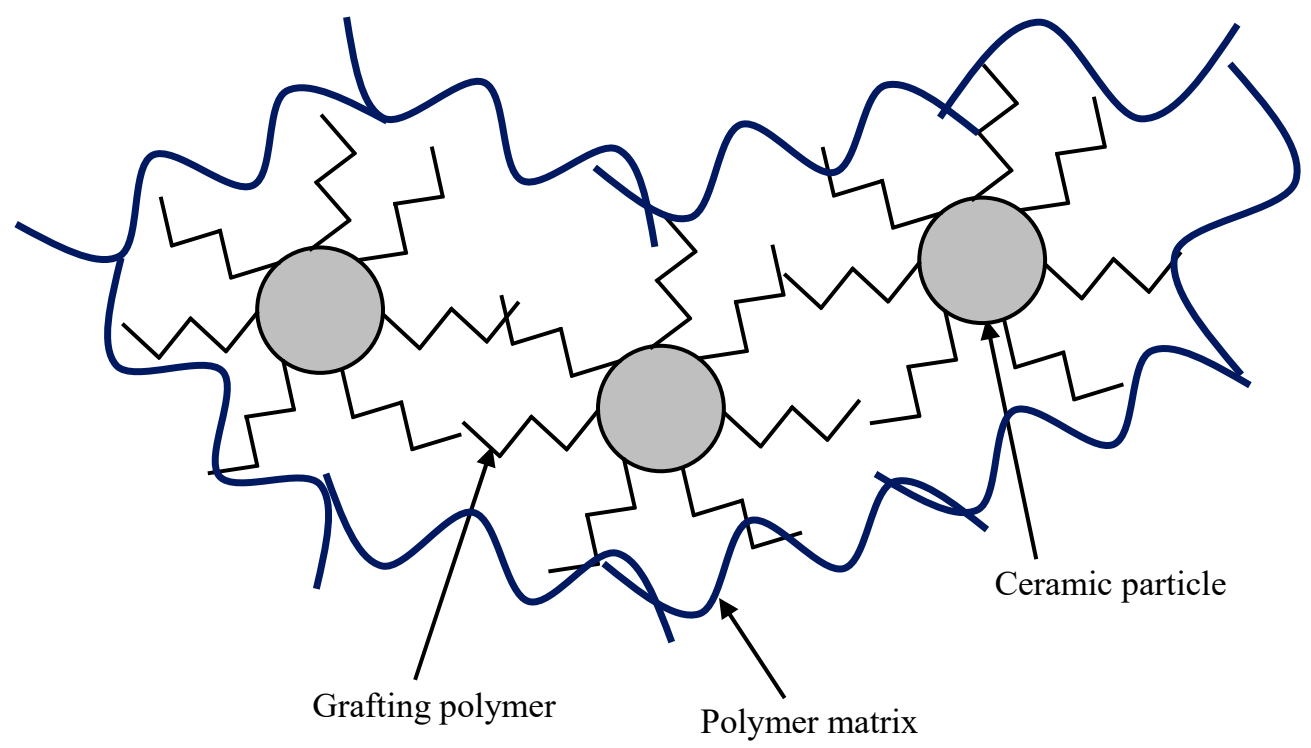

Figure 7. Schematic illustration of composite membrane using graft polymer chain on ceramic NPs. The grafting polymer suppress aggregation of the ceramic NPs and interacts with polymer matrixes, improving stability of the ceramic NPs in the polymer matrixes. 
Table 11. Grafted ceramic NPs-polymer membranes.

\begin{tabular}{|c|c|c|}
\hline Grafted Ceramic NPs & Host Polymer & Reference \\
\hline PHEMAb-PMMA@-SiO ${ }_{2}^{(1)}$ & PVDF & [184] \\
\hline silylated ZSM-5 & PDMS & [57] \\
\hline Polyester-MWCNT & PVDF & [185] \\
\hline PEG-GO & PVDF-co-HFP & [186] \\
\hline PMMA-CNT & PVDF & [58] \\
\hline PEG-nanodiamond & CA & [187] \\
\hline PMMA-SiO 2 & PES & [188] \\
\hline P(PEGMA)-GO & PSf & [189] \\
\hline${\mathrm{PSBMA}-\mathrm{MoS}_{2}}^{(2)}$ & PES & [190] \\
\hline
\end{tabular}

(1) PHEMAb-PMMA: poly(hydroxyethyl methacrylate)-block-poly(methyl methacrylate). (2) PSBMA: 2-methacryloyloxy ethyl dimethyl (3-sulfopropyl)-ammonium hydroxide sulfobetaine methacrylate.

The introduction of certain grafted polymer chains onto ceramic NPs clearly shows improving dispersity and compatibility of ceramic NPs with polymer matrix, resulting in enhancement in performance of the nanocomposite membranes. By grafting various types of polymers, not only tailoring the properties but also adding on one or more new functions to the nanocomposite membranes. However, the introduction of a complicated functional group on the surface of ceramic NPs needs rather complicated processing steps, making membrane production difficult and costly. Finding effective and simple functional groups and the development of novel functionalizing processes would be desirably required.

\subsection{Modification of Polymers}

Another direction to improve the compatibility between ceramic and polymeric components is the modification of polymeric matrixes by introducing functional groups that can interact with ceramic NPs. Polar groups such as sulfonic and carboxyl groups can provide active sites to capture on the surface of ceramic components as well as an increase in hydrophilicity [191-193].

\subsubsection{Modification of Bulk Polymer Matrix}

PVDF contains fluorine atoms, which exhibit a high electronegativity, in its polymer chain. Therefore, a negatively charged fluorine atom and positively charged adjacent hydrogen atom can contribute the hydrogen bond to surface hydroxyl groups on certain ceramic NPs. To further stabilize ceramic NPs, grafting of other polymers containing polar groups has been performed. For example, Zhang et al. grafted poly(acrylic acid) into PVDF membrane [97]. Carboxyl groups in poly (acrylic acid) (PAA)-grafted PVDF can interact with $\mathrm{Ti}(\mathrm{OBu})_{4}$ that is a precursor for $\mathrm{TiO}_{2}$. As a result, $\mathrm{TiO}_{2} \mathrm{NPs}$ are uniformly dispersed in the PAA-grafted PVDF composite membrane. A similar study is performed using CA as a polymer and TEOS (tetraethyl orthosilicate) as a precursor for $\mathrm{SiO}_{2}$ [194] and poly-dopamine (PDA)-poly-ethyleneimine (PEI)-g-poly-acrylonitrile (PAN) as a polymer and $\mathrm{Zr}\left(\mathrm{SO}_{4}\right)_{2}$ as a precursor for $\mathrm{ZrO}_{2}$ [195]. PDA is also employed to immobilize Ag NPs in PSf UF membranes [196,197].

Adding a component into the polymeric matrix is also an effective method, but adding an appropriate polymer does not require the polymerization like the grafting mentioned above. Thus, the functional polymeric matrix can be embedded easily. For example, mixing the triblock copolymer PEO-PPO (poly-phenyleneoxide)-PEO, which contains moieties that can interact with both organic and inorganic components, into PES UF membrane can improve the interfacial compatibility with $\mathrm{TiO}_{2} \mathrm{NPs}$ [198]. As other additives, PDA (polydopamine) has been exclusively researched [198-200]. In this strategy, many polymers with moieties which can interact with both polymeric and ceramic components, can be good candidates as the additives. There are still a lot of room to develop suitable additives in this strategy. 


\subsubsection{Surface Modification of Polymer Matrixes}

In the TFN membrane, ceramic NPs are supported on polymer matrixes. Therefore, surface modification of polymer matrixes has been extensively studied in order to prepare stable TFN membranes. The modifications have been largely performed to solid polymers, rather than the polymer solution. For example, $\gamma$-methacryloxy propyl trimethoxy silane (MPTS) monomer is polymerized (grafted) onto the PVDF solid membrane and then hydroxyl-rich $\mathrm{TiO}_{2}, \mathrm{SiO}_{2}$ and $\beta-\mathrm{FeOOH}$ are introduced [201]. The ceramic NPs were then firmly anchored in the grafted poly-MPTS layer and the ceramic NPs were stable even under ultrasonication for $30 \mathrm{~min}$. The same effect was observed in (3-aminopropyl)triethoxysilane grafted PVDF with $\mathrm{SiO}_{2}$ NPs membrane [202] and trimesoyl chloride which reacts with Si-OH groups, grafted PVDF membrane [203]. Additionally, functional complexes such as polyoxometalate could be immobilized onto the surface modified polymer membranes [204].

Recently, in order to create oxygen-containing functional groups on the polymeric membrane surface, plasma treatment is applied. For example, PP (Polypropylene) membrane was treated with the $\mathrm{O}_{2}$ plasma followed by the dip coating of $\mathrm{TiO}_{2}$ NPs [205]. By the $\mathrm{O}_{2}$ plasma treatment, the $\mathrm{C}=\mathrm{O}$ stretching band was formed on the PP membrane, which facilitates stabilizing $\mathrm{TiO}_{2}$ NPs. Additionally, the oxygen-containing functional groups were prepared on PVDF membrane by Ar plasma treatment, followed by oxygen exposure [206]. The functional groups facilitated to graft PAA thin layer on the PVDF membrane. The PAA layer helped immobilize $\mathrm{TiO}_{2} \mathrm{NPs}$ by the coordination of $\mathrm{Ti}^{4+}$ to carboxylic groups. As a result, the membrane possesses high hydrophilicity, water flux, and oil rejection rate. In another example, negatively charged PMAA (Polymethacrylic acid) chains are created onto the PVDF membrane surface via plasma-induced grafting polymerization [207]. Carboxyl moieties on PMAA acted as the binding sites to attract amino-grafted $\mathrm{SiO}_{2} \mathrm{NPs}$. In general, the plasma treatment is able to give rise to stable composite membranes. Nonetheless, further research is needed to clarify the exact effect of the plasma treatment in the performance of nanocomposite membranes.

\subsection{Direct Deposition of Ceramic NPs in Polymer Matrixes}

In situ growth of inorganic components on membrane surfaces cannot only improve the compatibility between the two components, but also provide ease of tailoring the inorganic layers. This strategy was first proposed by Xu et al. [208-210], where the creation of an intermediate layer on polymer membrane surface could capture precursors of inorganic particles, which are then converted into inorganic NPs on the membranes. The observed difference from the modification of the polymer surface described in the previous section is attributed that surface modified-polymer captures precursors of ceramic NPs, not directly captures ceramic NPs.

For example, PAA brushes are grafted on PP membrane, where the PAA-PP membrane is soaked into $\mathrm{CaCl}_{2}$ solution and then $\mathrm{Na}_{2} \mathrm{CO}_{3}$ solution. The $\mathrm{COO}^{-}$groups in the PP brushes captures $\mathrm{Ca}^{2+}$ followed by $\mathrm{CaCO}_{3}$ formation through reaction with $\mathrm{Na}_{2} \mathrm{CO}_{3}$, resulting in $\mathrm{CaCO}_{3}$ deposition on the membrane (Figure 8) [211]. The PAA intermediate layer could not only provide binding sites for $\mathrm{CaCO}_{3}$ growth but also stabilize the amorphous $\mathrm{CaCO}_{3}$ to control the mineral layer thickness. In the follow-up works, it was found that the PDA/PEI layer could provide positive amino groups for silicification and catechol groups for chelating metal ions. Rigid hydrophilic ceramic coatings showed excellent anti-oil properties in water, enabling these to be used in oil-in-water emulsion separation [212-214]. Such properties are also desirable in Li-ion battery separators to improve electrolyte wetting and resist thermal shrinkage [215].

Since the PDA-based interlayers being used, controlled growths of nickel-cobalt layered double hydroxides on a PDA-modified PVDF [216] and $\mathrm{ZrO}_{2}$ on PDA/PEI [195] have been studied. Compared with a single intermediate PDA layer, an additional positively charged CS layer could overcome the partial congregating of PDA and served as 
a smooth platform for uniform in situ growth of $\mathrm{SiO}_{2}$, leading to a dense and defect-free $\mathrm{SiO}_{2}$ layer [217]. Other groups have also studied this strategy [218-221].

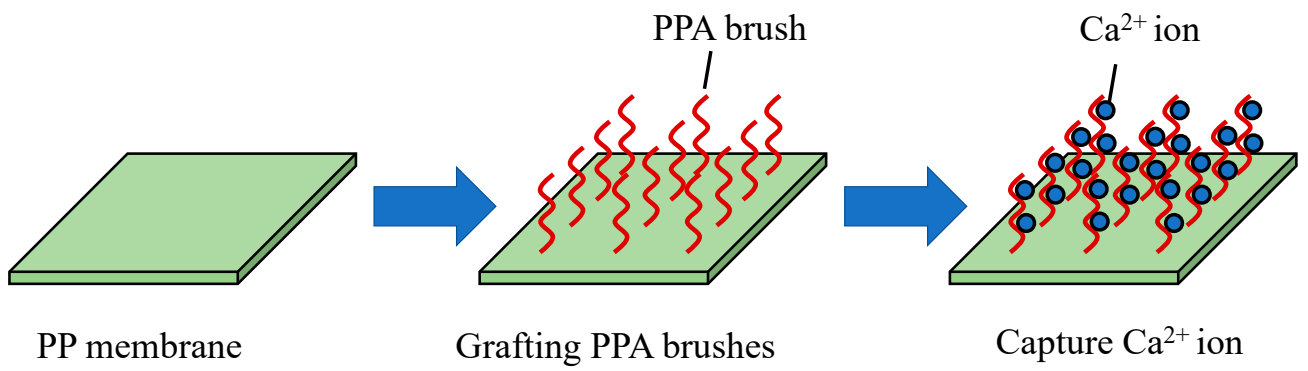

Figure 8. Preparation of $\mathrm{CaCO}_{3}$ mineral-coated membrane.

The in situ growth of inorganic NPs supported by grafting functional polymer components can form rather uniform and stable inorganic particles, leading to superior membrane performance. The popularization of this technique largely relates to the simplification in grafting processes of functional polymer components and the in situ growth process of inorganic components. For the in situ growth process, a moderate heating is sometimes performed, and however, the process could cause a slight change in the level of porosity and pore sizes of the polymer component. The grafting and growing processes must be chosen carefully.

As an alternative method for in situ growth of inorganic components on polymer membranes, surface coating techniques can be applied. Among the surface coating techniques, the Atomic Layer Deposition (ALD) technique is the most widely studied for the deposition of inorganic particles on polymeric membranes [222]. In a typical ALD process, reactive precursor vapors of inorganic materials are pulsed into a chamber alternately under the protection of inert gas, leading to the layer-by-layer growth of metals, metal oxides, and even organic materials [223,224]. The deposition of a series of oxides $\mathrm{ZnO}$, $\mathrm{Al}_{2} \mathrm{O}_{3}, \mathrm{TiO}_{2}$, and $\mathrm{SnO}_{2}$ on PVDF membranes, can be performed by the ALD and tested anti-crude-oil properties (Figure 9) [225]. The ALD would be a good choice to prepare TFN membranes because the ALD can deposit various inorganic layers with a controllable thickness. However, for certain extremely inert substrate materials (e.g., PP or PTFE), ALD coating becomes difficult and an effective surface treatment is needed [226-228]. The TFN membranes prepared by the ALD technique is summarized in a review [222]. The application of the ALD technique for membrane preparation is a relatively new topic. Further intensive research is needed.
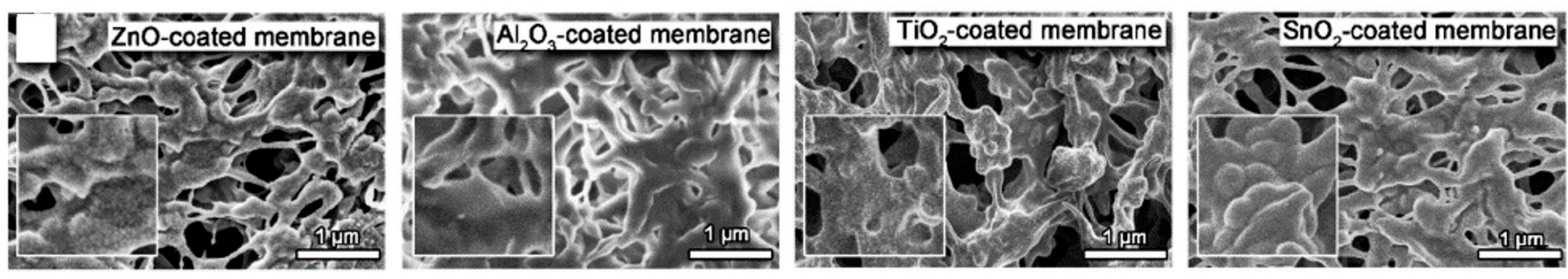

Figure 9. $\mathrm{ZnO}, \mathrm{Al}_{2} \mathrm{O}_{3}, \mathrm{TiO}_{2}$ and $\mathrm{SnO}_{2}$ deposited on PVDF membrane by ALD [225]. Reproduced with permission. Copyright in 2018, American Chemical Society.

\subsection{Ceramic-Supported Polymer Membranes}

For the ceramics-supported polymer membranes, in addition to interfacial adhesion, penetration of polymer solution into pores of ceramic support can inhibit the formation of a dense and defect-free polymeric separation layer on the ceramic support. To prevent the penetration, an increase in viscosity of polymer solution and pre-wetting pores of ceramic 
support has been performed [223]. The pores of ceramic support are filled with water first and then polymer solution was cast on the ceramic support. Because of the blocking effect of the filled water, the penetration of polymer solution can be greatly reduced. The interfacial adhesion strength between the polymeric layer and ceramic supports must be high enough to ensure long-term operation of the ceramic-supported polymeric membrane. The interfacial adhesion is largely influenced by the roughness of ceramic support and viscosity of polymer solution [229]. An increase in the adhesion strength was obtained by lowering viscosity and roughing the support surface. For example, Jin's group developed a home-made in situ nano-indentation/scratch technique and studied critical load on the interfacial adhesion of the PDMS $/ \mathrm{Al}_{2} \mathrm{O}_{3}$ membrane [230]. Recently, tubular $\mathrm{Al}_{2} \mathrm{O}_{3}$ substrate was dip-coated into PEI solution short time $(\sim 10 \mathrm{~s})$ to prevent the penetration of the polymer solution and then phase-inverted from both inner and outer surface of the substrate [231]. In this case, the penetration could be suppressed completely.

By contrast, interfacial polymerization can also be employed to prepare a thin polymeric layer directly on the ceramic support. For example, Chong et al. prepared a PA thin layer with a thickness of $30-40 \mathrm{~nm}$ on the $\mathrm{Al}_{2} \mathrm{O}_{3}$ tubular membrane by interfacial polymerization [153]. Xia et al. also succeeded in fabricating PA thin layer on the $\mathrm{Al}_{2} \mathrm{O}_{3}$ tubular UF membrane by interfacial polymerization [151]. The interfacial polymerization is suitable for tubular support which is difficult to be cast polymer solutions. Shi et al. deposited a PEI gutter layer on tubular $\mathrm{Al}_{2} \mathrm{O}_{3}$ support by dip coating, which enhances the adhesion of the PDMS top layer [232]. The third component must have high compatibility with both the ceramic support and the thin polymeric top layer.

As an alternative strategy, the silane grafting approach reveals enhancement of the interfacial adhesion and performance of ceramic-support polymer membranes for ultrafiltration of oil-water emulsions [233] and pervaporation [150]. In this approach, methoxysilane with polymer chains reacts with hydroxyl groups on the ceramic surface. The Si-O covalent improve surface adhesion with ceramic support and the polymer chains enhance compatibility with the polymeric top layer (Figure 10).

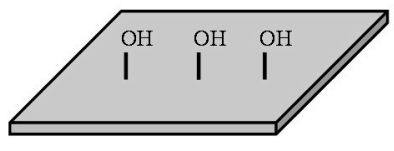

Ceramic support

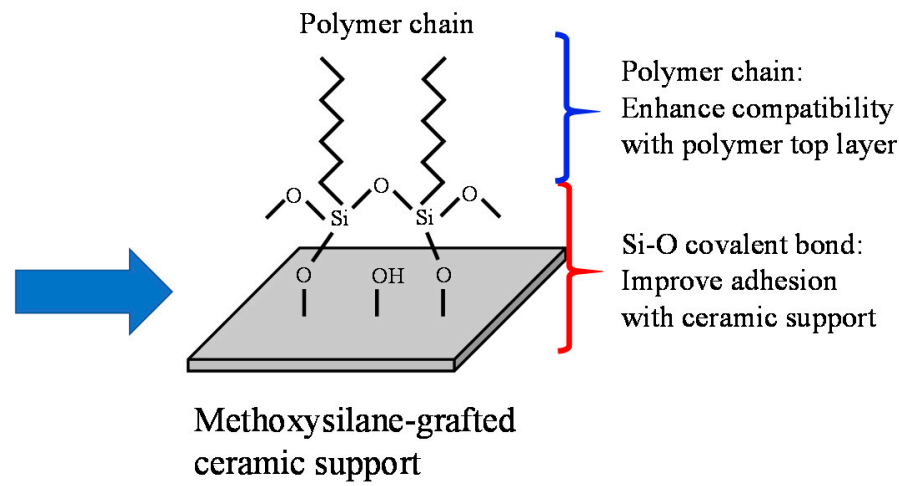

Figure 10. Fabrication of PDMS membrane supported on surface-grafted ceramic substrate.

\section{Perspective}

Ceramic-polymer composite membranes have been intensively researched in recent years. To successfully develop the designed types of composite membranes, different fabrication techniques have been established, especially to improve compatibility between ceramic and polymeric components. Tuning the overall membrane structure can dramatically change the physicochemical properties, such as the type and level of porosity, surface hydrophilicity, chemical and mechanical stabilities, which impact the overall filtration/separation performance. Additional functionalities such as antibacterial, photocatalytic, and antifouling properties can also be anchored in ceramic-polymer composite membranes. Well-designed ceramic-polymer composite membranes would be able to solve current problems of polymeric and ceramic membranes and be a good candidate for next generation membrane technology. 
To further develop into practical applications of the composite membranes, there are several perspectives and challenges, which are summarized as follows:

1. Fundamental study: Fundamental understandings for the influence of certain ceramic NPs on membrane structures and membrane performance is still unclear, in several cases. There have been several studies reporting influence of ceramic NPs on polymeric matrixes; however, the origin of the influence has not been researched in detail. As shown in Table 4, the influence of $\mathrm{TiO}_{2}, \mathrm{Al}_{2} \mathrm{O}_{3}$ and $\mathrm{ZrO}_{2}$ on the level of porosity and contact angle of polymeric matrix were different. However, it is still unclear how and what properties of the ceramic NPs influence the polymeric matrix. Detail studies on a relationship between surface properties of ceramic NPs, structures and performance of the membrane would be needed. This will help design new composite membranes.

2. Structural study: Structural studies of the composite membranes have mostly been carried out by observation of morphology using SEM and sometimes by EDS, FTIR and XPS. These rather simple structural analyses can lead to a wrong conclusion. For example, Fe-Boemite-PVB/PVDF membrane was prepared by (i) casting Boehmite-PVDF-PVB solution, (ii) immersing Boehmite-PVB-PVDF membrane into $\mathrm{FeSO}_{4}$ solution, and (iii) Reduction of $\mathrm{Fe}^{2+}$ on the Boehmite-PVB-PVDF membrane by $\mathrm{KBH}_{4}$ [234]. In the structural analysis of the membrane made by using SEM and FT-IR, the TFN-type membrane structure was envisioned. In the solution casting, the boemite particles could exist not only surface of the PVDF-PVB membrane, inside the PVDF-PVB membrane as well. $\mathrm{Fe}^{2+}$ ion would be captured by $\mathrm{OH}$ groups of boehmite inside the polymeric matrix. Thus, the membrane would be concluded as nanocomposite-type membrane, not TFN-type. The lack of structural analysis of membrane could cause misunderstanding of membrane structure, leading to the wrong conclusions.

3. Long-term stability: there are several research works conducted in improving the compatibility between ceramic NPs and polymeric matrix, as described. However, knowledge of long-term compatibility is still not enough. In short term studies, there have been suggestions to suppress the aggregation of NPs in composite membranes and nanoparticle leakage. Studies on long-term compatibility between ceramic NPs and polymeric matrix, change of the membrane properties and environmental impact by the nanoparticle leakage would be required. Particularly, in addition to photocatalytic properties by $\mathrm{TiO}_{2}$, photocurrent would oxidize and damage/change the polymeric matrix. This should become more prominent after any long-term usage. However, studies on extended long-term stability of the photocatalytic membranes have not been performed. To understand the stability of the membranes and fate of nanoparticles, several characterizations, e.g., leaching tests, scanning electron microphotographs of the membrane surface and cross-section, roughness and FTIR with attenuated total reflectance (ATR) scans of used membranes must be carried out.

4. Production cost: the expected application of the ceramic-polymer composite membranes for water treatment is still at a rather early stage. There are numerous laboratory-based works, but studies on large-scale production and industrial application have not been properly conducted [235]. More efforts have to be made to evaluate the long-term durability under the application conditions and cost-effectiveness including the supply of nanoparticles and methods for nanoparticle incorporation. Compared to current polymetric membranes, composite membranes require additional production processes, leading to higher production costs. More recently, novel fabrication techniques such as 3DP are emerging for membrane fabrication. Some of the new techniques have been applied for ceramic and polymeric membranes so far [236-238]; however, there were fewer for ceramic-polymer composite membranes. The 3DP would be able to reduce the production cost for the composite membranes, when properly developed. Give the $\mathrm{Al}_{2} \mathrm{O}_{3}$ membrane is several times more expensive than the PES polymeric membrane [164], development of cost-effective new ceramic 
NPs and the corresponding preparation process of composite membranes would be needed. Natural polymers, such as cellulose acetate and polysaccharide, normally possess polar groups in their structures, which can provide interacting sites for ceramic particles $[239,240]$. Additionally, the material cost of natural minerals such as kaolin, natural clay, etc. is much lower than $\mathrm{Al}_{2} \mathrm{O}_{3}$ [167]. Additionally, these natural minerals possess high hydrophilicity, which is expected to improve the hydrophilicity of composite membranes, if they are incorporated into the polymeric matrix. The usage of natural polymers and natural minerals would be a strategy to reduce the production cost of the composite membranes. Further study must be performed to reduce the production cost of the nanocomposite membranes.

Funding: This work was funded by the National Research Foundation Singapore (NRF-CRP17-2017-01).

Institutional Review Board Statement: Not applicable.

Informed Consent Statement: Not applicable.

Data Availability Statement: The data presented in this review paper are available in article.

Conflicts of Interest: The authors declare no conflict of interest.

\section{References}

1. Yang, Z.; Zhou, Y.; Feng, Z.; Rui, X.; Zhang, T.; Zhang, Z. A review on reverse osmosis and nanofiltration membranes for water purification. Polymers 2019, 11, 1252. [CrossRef]

2. Goh, P.S.; Ismail, A.F. A review on inorganic membranes for desalination and wastewater treatment. Desalination 2018, 434, 60-80. [CrossRef]

3. Fu, F.; Wang, Q. Removal of heavy metal ions from wastewaters: A review. J. Environ. Manag. 2011, 92, 407-418. [CrossRef]

4. Koros, W.J.; Zhang, C. Materials for next-generation molecularly selective synthetic membranes. Nat. Mater. 2017, 16, 289-297. [CrossRef]

5. Karakulski, K.; Gryta, M.; Morawski, A. Membrane processes used for potable water quality improvement. Desalination 2002, 145, 315-319. [CrossRef]

6. Humes, H.D.; Fissell, W.H.; Tiranathanagul, K. The future of hemodialysis membranes. Kidney Int. 2006, 69, 1115-1119. [CrossRef]

7. Nagarale, R.K.; Gohil, G.S.; Shahi, V.K. Recent developments on ion-exchange membranes and electro-membrane processes. Adv. Colloid Interface Sci. 2006, 119, 97-130. [CrossRef] [PubMed]

8. Darwano, H.; Vo Duy, S.; Sauve, S. A new protocol for the analysis of pharmaceuticals, pesticides, and hormones in sediments and suspended particulate matter from rivers and municipal wastewaters. Arch. Environ. Contam. Toxicol. 2014, 66, 582-593. [CrossRef]

9. Lee, A.; Elam, J.W.; Darling, S.B. Membrane materials for water purification: Design, development, and application. Environ. Sci. Water Res. Tech. 2016, 2, 17-42. [CrossRef]

10. Padaki, M.; Murali, R.S.; Abdullah, M.S.; Misdan, N.; Moslehyani, A.; Kassim, M.A.; Hilal, N.; Ismail, A.F. Membrane technology enhancement in oil-water separation: A review. Desalination 2015, 357, 197-207. [CrossRef]

11. Geise, G.M.; Lee, H.-S.; Miller, D.J.; Freeman, B.D.; McGrath, J.E.; Paul, D.R. Water purification by membranes: The role of polymer science. J. Polym. Sci. B Polume Phys. 2010, 48, 1685-1718. [CrossRef]

12. Gin, D.L.; Noble, R.D. Designing the next generation of chemical separation membranes. Science 2011, 332, 674-676. [CrossRef]

13. Zhu, J.; Tian, M.; Hou, J.; Wang, J.; Lin, J.; Zhang, Y.; Liu, J.; Van der Bruggen, V. Surface zwitterionic functionalized graphene oxide for a novel loose nanofiltration membrane. J. Mater. Chem. A 2016, 4, 1980-1990. [CrossRef]

14. Mohammad, A.W.; Teow, Y.H.; Ang, W.L.; Chung, Y.T.; Oatley-Radcliffe, D.L.; Hilal, N. Nanofiltration membranes review: Recent advances and future prospects. Desalination 2015, 356, 226-254. [CrossRef]

15. Hilal, N.; Al-Zoubi, H.; Darwish, N.A.; Mohamma, A.W.; Abu Arabi, M. A comprehensive review of nanofiltration membranes: Treatment, pretreatment, modelling, and atomic force microscopy. Desalination 2004, 170, 281-308. [CrossRef]

16. Geise, G.M.; Paul, D.R.; Freeman, B.D. Fundamental water and salt transport properties of polymeric materials. Prog. Polym. Sci. 2014, 39, 1-42. [CrossRef]

17. Lee, K.P.; Arnot, T.C.; Mattia, D. A review of reverse osmosis membrane materials for desalination-Development to date and future potential. J. Membr. Sci. 2011, 370, 1-22. [CrossRef]

18. ElMekawy, A.; Hegab, H.M.; Pant, D. The near-future integration of microbial desalination cells with reverse osmosis technology. Energy Environ. Sci. 2014, 7, 3921-3933. [CrossRef]

19. He, Z.; Lyu, Z.; Gu, Q.; Zhang, L.; Wang, J. Ceramic-based membranes for water and wastewater treatment. Colloids Surf. A 2019, 578, 123513. [CrossRef]

20. Ng, L.Y.; Mohammad, A.W.; Leo, C.P.; Hilal, N. Polymeric membranes incorporated with metal/metal oxide nanoparticles: A comprehensive review. Desalination 2013, 308, 15-33. [CrossRef] 
21. Gitis, V.; Rothenberg, G. Ceramic Membranes: New Opportunities and Practical Applications; Willey-VCH Verlag GmbH\&Co.: Weinheim, Germany, 2016.

22. DeFriend, K.A.; Wiesner, M.R.; Barron, A.R. Alumina and aluminate ultrafiltration membranes derived from alumina nanoparticles. J. Membr. Sci. 2003, 224, 11-28. [CrossRef]

23. Li, F.B.; Yang, Y.; Fan, Y.Q.; Xing, W.H.; Wang, Y. Modification of ceramic membranes for pore structure tailoring: The atomic layer deposition route. J. Membr. Sci. 2012, 397, 17-23. [CrossRef]

24. Wen, Q.; Di, J.; Zhao, Y.; Wang, Y.; Jiang, L.; Yu, J. Flexible inorganic nanofibrous membranes with hierarchiral porosity for efficient water purification. Chem. Sci. 2013,4, 4378-4382. [CrossRef]

25. Liu, L.; Liu, Z.Y.; Bai, H.W.; Sun, D.D. Concurrent filtration and solar photocatalytic disinfection/degradation using high performance $\mathrm{Ag} / \mathrm{TiO}_{2}$ nanofiber membrane. Water Res. 2012, 46, 1101-1112. [CrossRef]

26. Ahmad, A.L.; Abdulkarim, A.A.; Ooi, B.S.; Ismail, S. Recent development in additives modifications of polyethersulfone membrane for flux enhancement. Chem. Eng. J. 2013, 223, 246-267. [CrossRef]

27. Saljoughi, E.; Mousavi, S.M. Preparation and characterization of novel polysulfone nanofiltration membranes for removal of cadmium from contaminated water. Sep. Purif. Tech. 2012, 90, 22-30. [CrossRef]

28. Yuliwati, E.; Ismail, A.F. Effect of additives concentration on the surface properties and performance of PVDF ultrafiltration membranes for refinery produced wastewater treatment. Desalination 2011, 273, 226-234. [CrossRef]

29. Liu, F.; Hashim, N.A.; Liu, Y.; Abed, M.R.M.; Li, K. Progress in the production and modification of PVDF membranes. J. Membr. Sci. 2011, 375, 1-27. [CrossRef]

30. Yu, S.; Zhang, X.; Li, F.; Zhao, X. Poly(vinyl pyrrolidone) modified poly(vinylidene fluoride) ultrafiltration membrane via a two-step surface grafting for radioactive wastewater treatment. Sep. Purif. Techol. 2018, 194, 404-409. [CrossRef]

31. Lohokare, H.R.; Muthu, M.R.; Agarwal, G.P.; Kharul, U.K. Effective arsenic removal using polyacrylonitrile-based ultrafiltration (UF) membrane. J. Membr. Sci. 2008, 320, 159-166. [CrossRef]

32. Kim, I.C.; Yun, H.G.; Lee, K.H. Preparation of asymmetric polyacrylonitrile membrane with small pore size by phase inversion and post-treatment process. J. Membr. Sci. 2002, 199, 75-84. [CrossRef]

33. Unlu, D. Recovery of cutting oil from wastewater by pervaporation process using natural clay modified PVA membrane. Water Sci. Tech. 2019, 80, 2404-2411. [CrossRef] [PubMed]

34. Moradi, E.; Ebahimzdeh, H.; Mehrani, Z.; Asgharinezhad, A.A. The efficient removal of methylene blue from water samples using three-dimensional poly(vinyl alcohol)/starch nanofiber membrane as a green nanosorbent. Environ. Sci. Poll. Res. 2019, 26, 35071-35081. [CrossRef]

35. Esmaeili, N.; Boyd, S.E.; Brown, C.L.; Gray, E.M.A.; Webb, C.J. Improving the gas-separation properties of PVAc-Zeolite 4A mixed-matrix membranes through nano-sizing silanation of the Zeolite. Chem. Phys. Chem. 2019, 20, $1590-1606$.

36. Goossens, I.; Van Haute, A. The influence of mineral fillers on the membrane properties of high flux asymmetric cellulose acetate reverse osmosis membranes. Desalination 1976, 18, 203-214. [CrossRef]

37. Vu, D.Q.; Koros, W.J.; Miller, S.J. Mixed matrix membranes using carbon molecular sieves: I. Preparation and experimental results. J. Membr. Sci. 2003, 211, 311-334. [CrossRef]

38. Chung, T.-S.; Jiang, L.Y.; Li, Y.; Kulprathipanja, S. Mixed matrix membranes (MMMs) comprising organic polymers with dispersed inorganic fillers for gas separation. Prog. Polym. Sci. 2007, 32, 483-507. [CrossRef]

39. Aroon, M.A.; Ismail, A.F.; Matsuura, T.; Montazer-Rahmati, M.M. Performance studies of mixed matrix membranes for gas separation: A review. Sep. Purif. Tech. 2010, 75, 229-242. [CrossRef]

40. Nambikkattu, J.; Kaleekkal, N.J.; Jacob, J.P. Metal ferrite incorporated polysulfone thin-film nanocomposite membranes for wastewater treatment. Environ. Sci. Poll. Res. 2021, 28, 11915-11927. [CrossRef]

41. Kugarajah, V.; Dharmalingam, S. Effect of silver incorporated sulphonated poly ether ether ketone membranes on microbial fuel cell performance and microbial community analysis. Chem. Eng. J. 2021, 415, 128961. [CrossRef]

42. Mehta, R.; Brahmbhatt, H.; Bhojani, G.; Mukherjee, M.; Bhattacharya, A. Poly(piperizinamide) with copper ion composite membranes: Application for mitigation of hexaconazole from water and combat microbial contamination. J. Hazard. Mater. 2019, 376, 102-111. [CrossRef]

43. Liu, N.; Li, X.; Li, J.; Cao, Y.; Feng, L. Hierarchical architectures of Ag cluster deposited biomimetic membrane: Synthesis, emulsion separation, catalytic and antibacterial performance. Sep. Purif. Tech. 2020, 241, 116733. [CrossRef]

44. Liu, G.; Wei, W.; Jin, W.; Xu, N. Polymer/ceramic composite membranes and their application in pervaporation process. Chin. J. Chem. Eng. 2012, 20, 62-70. [CrossRef]

45. Shen, L.; Huang, Z.; Liu, Y.; Li, R.; Xu, Y.; Jakaj, G.; Lin, H. Polymeric membranes incorporated with ZnO nanoparticles for membrane fouling mitigation: A brief review. Front. Chem. 2020, 8, 224. [CrossRef] [PubMed]

46. Errahmani, K.B.; Benhabiles, O.; Bellebia, S.; Bengharez, Z.; Goosen, M.; Mahmoudi, H. Photocatalytic nanocomposite polymer$\mathrm{TiO}_{2}$ membranes for pollutant removal from wastewater. Catalysts 2021, 11, 402. [CrossRef]

47. Soria, R.B.; Zhu, J.; Gonza, I.; Bruggen, B.V.; Luis, P. Effect of $\left(\mathrm{TiO}_{2}: \mathrm{ZnO}\right)$ ratio on the anti-fouling properties of bio-inspired nanofiltration membranes. Sep. Purif. Tech. 2020, 251, 117280. [CrossRef]

48. Darabi, R.R.; Jahanshahi, M.; Peyravi, M. A support assisted by photocatalytic $\mathrm{Fe}_{3} \mathrm{O}_{4} / \mathrm{ZnO}$ nanocomposite for thin-film forward osmosis membrane. Chem. Eng. Res. Des. 2018, 133, 11-25. [CrossRef] 
49. Ghanbari, M.; Emadzadeh, D.; Lau, W.J.; Matsuura, T.; Davoody, M.; Ismail, A.F. Super hydrophilic TiO $2 / \mathrm{HNT}_{2}$ nanocomposites as a new approach for fabrication of high performance thin film nanocomposite membranes for FO application. Desalination 2015, 371, 104-114. [CrossRef]

50. Ma, N.; Wei, J.; Liao, R.; Tang, C.Y. Zeolite-polyamide thin film nanocomposite membranes: Towards enhanced performance for forward osmosis. J. Membr. Sci. 2012, 405-406, 149-157.

51. Hoek, E.M.V.; Ghosh, A.K.; Huang, X.; Liong, M.; Zink, J.I. Physical-chemical properties, separation performance, and fouling resistance of mixed-matrix ultrafiltration membranes. Desalination 2011, 283, 89-99. [CrossRef]

52. Samei, M.; Iravaninia, M.; Mohammadi, T.; Asadi, A.A. Solution diffusion modeling of a composite PVA/fumed silica ceramic supported membrane. Chem. Eng. Process. 2016, 109, 11-19. [CrossRef]

53. Perera, M.G.N.; Galagedara, Y.R.; Ren, Y.; Jayaweera, M.; Zhao, Y.; Weerasooriya, R. Fabrication of fullerenol-incorporated thin-film nanocomposite forward osmosis membranes for improved desalination performances. J. Polym. Res. 2018, 25, 199. [CrossRef]

54. Zhang, F.; Zhang, W.; Yu, Y.; Deng, B.; Li, J.; Jin, J. Sol-gel preparation of PAA-g-PVDF/TiO 2 nanocomposite hollow fiber membranes with extremely high water flux and improved antifouling property. J. Membr. Sci. 2013, 432, 25-32. [CrossRef]

55. Salazar, H.; Martins, P.M.; Santos, B.; Fernandes, M.M.; Reizabal, A.; Sebastian, V.; Batelho, G.; Tavares, C.J.; Vilas-Vilela, J.L.; Lanceros-Mendez, S. Photocatalytic and antimicrobial multifunctional nanocomposite membranes for emerging pollutants water treatment applications. Chemosphere 2020, 250, 126299. [CrossRef] [PubMed]

56. Ahsani, M.; Hazrati, H.; Javadi, M.; Ulbricht, M.; Yegani, R. Preparation of antibiofouling nanocomposite PVDF/Ag-SiO 2 membrane and long-term performance evaluation in the MBR system fed by real pharmaceutical wastewater. Sep. Purif. Tech. 2020, 249, 116938. [CrossRef]

57. Liu, G.; Xiangli, F.; Wei, W.; Liu, S.; Jin, W. Improved performance of PDMS/ceramic composite pervaporation membranes by ZSM-5 homogeneously dispersed in PDMS via a surface graft/coating approach. Chem. Eng. J. 2011, 174, 495-503. [CrossRef]

58. Ma, W.; Zhao, Y.; Li, Y.; Zhang, P.; Cao, Z.; Yang, H.; Liu, C.; Tao, G.; Gong, F.; Matsuyama, H. Synthesis of hydrophilic carbon nanotubes by grafting poly(methyl methacrylate) via click reaction and its effect on poly(vinylidene fluoride)-carbon nanotube composite. Appl. Surf. Sci. 2018, 435, 79-90. [CrossRef]

59. Chung, Y.T.; Mahmoudi, E.; Mohammad, A.W.; Benamor, A.; Johnson, D.; Hilal, N. Development of polysulfone-nanohybrid membranes using ZnO-GO composite for enhanced antifouling and antibacterial control. Desalination 2017, 402, 123-132. [CrossRef]

60. Kim, H.J.; Pant, H.R.; Kin, J.H.; Choi, N.J.; Kim, C.S. Fabrication of multifunctional $\mathrm{TiO}_{2}$-fly ash/polyurethane nanocomposite membrane via electrospinning. Ceram. Int. 2014, 40, 3023-3029. [CrossRef]

61. Yin, J.; Deng, B. Polymer-matrix nanocomposite membranes for water treatment. J. Membr. Sci. 2015, 479, 256-275. [CrossRef]

62. Wang, Y.; Li, L.; Zhang, X.; Li, J.; Wang, J.; Li, N. Polyvinylamine/amorphous metakaolin mixed-matrix composite membranes with facilitated transport carriers for highly efficient $\mathrm{CO}_{2} / \mathrm{N}_{2}$ separation. J. Membr. Sci. 2020, 599, 117828. [CrossRef]

63. Daraei, P.; Ghaemi, N. Synergistic effect of Cloisite 15A and 30B nanofillers on the characteristics of nanocomposite polyethersulfone membrane. Appl. Clay Sci. 2019, 172, 96-105. [CrossRef]

64. Shokri, E.; Shahed, E.; Hermani, M.; Etemadi, H. Towards enhanced fouling resistance of PVC ultrafiltration membrane using modified montmorillonite with folic acid. Appl. Clay Sci. 2021, 200, 105906. [CrossRef]

65. Paz, Y. Application of $\mathrm{TiO}_{2}$ photocatalysis for air treatment: Patents' overview. Appl. Catal. B 2010, 99, 448-460. [CrossRef]

66. Rahimpour, A.; Madaeni, S.S.; Taheri, A.H.; Mansourpanah, Y. Coupling $\mathrm{TiO}_{2}$ nanoparticles with UV irradiation for modification of polyethersulfone ultrafiltration membranes. J. Membr. Sci. 2008, 313, 158-169. [CrossRef]

67. Damodar, R.A.; You, S.-J.; Chou, H.-H. Study the self cleaning, antibacterial and photocatalytic properties of $\mathrm{TiO}_{2}$ entrapped PVDF membranes. J. Hazard. Mater. 2009, 172, 1321-1328. [CrossRef]

68. Yu, L.-Y.; Shen, H.-M.; Xu, Z.-L. PVDF-TiO ${ }_{2}$ composite hollow fiber ultrafiltration membranes prepared by $\mathrm{TiO}_{2}$ sol-gel method and blending method. J. Appl. Polym. Sci. 2009, 113, 1763-1772. [CrossRef]

69. Zhou, A.; Jia, R.; Wang, Y.; Sun, S.; Xin, X.; Wang, M.; Zhao, Q.; Zhu, H. Abatement of sulfadiazine in water under a modified ultrafiltration membrane (PVDF-PVP-TiO 2 -dopamine) filtration-photocatalysis system. Sep. Purif. Tech. 2020, $234,116099$. [CrossRef]

70. Razmjou, A.; Mansouri, J.; Chen, V. The effects of mechanical and chemical modification of $\mathrm{TiO}_{2}$ nanoparticles on the surface chemistry, structure and fouling performance of PES ultrafiltration membranes. J. Membr. Sci. 2011, 378, 73-84. [CrossRef]

71. Madaeni, S.S.; Zinadini, S.; Vatanpour, V. A new approach to improve antifouling property of PVDF membrane using in situ polymerization of PAA functionalized $\mathrm{TiO}_{2}$ nanoparticles. J. Membr. Sci. 2011, 380, 155-162. [CrossRef]

72. Sotto, A.; Boromand, A.; Balta, S.; Kim, J.; Van der Bruggen, B. Doping of polyethersulfone nanofiltration membranes: Antifouling effect observed at ultralow concentrations of $\mathrm{TiO}_{2}$ nanoparticles. J. Mater. Chem. 2011, 21, 10311-10320. [CrossRef]

73. Hamid, N.A.A.; Ismail, A.F.; Matsuura, T.; Zularisam, A.W.; Lau, W.J.; Yuliwati, E.; Abdullah, M.S. Morphological and separation performance study of polysulfone/titanium dioxide $\left(\mathrm{PSF} / \mathrm{TiO}_{2}\right)$ ultrafiltration membranes for humic acid removal. Desalination 2011, 273, 85-92. [CrossRef]

74. Abedini, R.; Mousavi, S.M.; Aminzadeh, R. A novel cellulose acetate (CA) membrane using $\mathrm{TiO}_{2}$ nanoparticles: Preparation, characterization and permeation study. Desalination 2011, 277, 40-45. [CrossRef] 
75. Rahimpour, A.; Jahanshahi, M.; Rajaeian, B.; Rahimnejad, M. $\mathrm{TiO}_{2}$ entrapped nano-composite PVDF/SPES membranes: Preparation, characterization, antifouling and antibacterial properties. Desalination 2011, 278, 343-353. [CrossRef]

76. Oh, S.J.; Kim, N.; Lee, Y.T. Preparation and characterization of $\mathrm{PVDF} / \mathrm{TiO}_{2}$ organic-inorganic composite membranes for fouling resistance improvement. J. Membr. Sci. 2009, 345, 13-20. [CrossRef]

77. Ngang, H.P.; Ooi, D.S.; Ahmad, A.L.; Lai, S.O. Preparation of $\mathrm{PVDF}^{-\mathrm{TiO}_{2}}$ mixed-matrix membrane and its evaluation on dye adsorption and UV-cleaning properties. Chem. Eng. J. 2012, 197, 359-367. [CrossRef]

78. Sun, F.; Ren, H.-T.; Li, T.-T.; Huang, S.-Y.; Zhang, Y.; Lou, C.-W.; Lin, J.-H. Bioinspired design of underwater superoleophobic Poly(N-isopropylacrylamide)/polyeacrylonitrile/ $\mathrm{TiO}_{2}$ nanofibrous membranes for highly efficient oil/water separation and photocatalysis. Environ. Res. 2020, 186, 109494. [CrossRef]

79. Yaacob, N.; Goh, P.S.; Ismail, A.F.; Nazri, N.A.M.; Ng, B.C.; Abidin, M.N.Z.; Yogarathinam, L.T. ZrO $2-\mathrm{TiO}_{2}$ incorporated PVDF dual-layer hollow fiber membrane for oily wastewater treatment: Effect of air gap. Membrane 2020, 10, 124. [CrossRef] [PubMed]

80. Gharebakhsh, H.; Panahi, H.A.; Toosi, M.R.; Hassani, A.H.; Moniri, E. Application of polyamide thin-film composite layered on polysulfone- $\mathrm{GO} / \mathrm{TiO}_{2}$ mixed membranes for removal of nitrotoluene derivatives from petrochemical wastewaters. Environ. Sci. Poll. Res. 2020, 27, 42481-42494. [CrossRef]

81. Sun, M.; Su, Y.; Mu, C.; Jiang, Z. Improved antifouling property of PES ultrafiltration membranes using additive of silica-PVP nanocomposite. Ind. Eng. Chem. Res. 2010, 49, 790-796. [CrossRef]

82. Jomekian, A.; Mansoori, S.A.A.; Monirimanesh, N. Synthesis and characterization of novel PEO-MCM-41/PVDC nanocomposite membrane. Desalination 2011, 276, 239-245. [CrossRef]

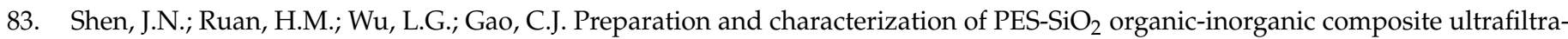
tion membrane for raw water pretreatment. Chem. Eng. J. 2011, 168, 1272-1278. [CrossRef]

84. Muriithi, B.; Loy, D.A. Processing, morphology, and water uptake of nafion/Ex-situ stöber silica nanocomposite membranes as a function of particle size. ACS Appl. Mater. Interfaces 2012, 4, 6766-6773. [CrossRef]

85. Huang, J.; Zhang, K.; Wang, K.; Xie, Z.; Ladewig, B.; Wang, H. Fabrication of polyethersulfone-mesoporous silica nanocomposite ultrafiltration membranes with antifouling properties. J. Membr. Sci. 2012, 423-424, 362-370. [CrossRef]

86. $\mathrm{Wu}, \mathrm{H}$.; Tang, B.; $\mathrm{Wu}, \mathrm{P}$. Development of novel $\mathrm{SiO}_{2}-\mathrm{GO}$ nanohybrid/poly-sulfone membrane with enhanced performance. J. Membr. Sci. 2014, 451, 94-102. [CrossRef]

87. Yan, L.; Hong, S.; Li, M.L.; Li, Y.S. Application of the $\mathrm{Al}_{2} \mathrm{O}_{3}$-PVDF nanocomposite tubular ultrafiltration (UF) membrane for oily wastewater treatment and its antifouling research. Sep. Purif. Tech. 2009, 66, 347-352. [CrossRef]

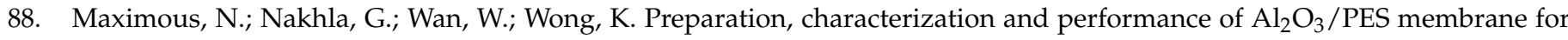
wastewater filtration. J. Membr. Sci. 2009, 341, 67-75. [CrossRef]

89. Maximous, N.; Nakhla, G.; Wong, K.; Wan, W. Optimization of $\mathrm{Al}_{2} \mathrm{O}_{3} /$ PES membranes for wastewater filtration. Sep. Purif. Tech. 2010, 73, 294-301. [CrossRef]

90. Maximous, N.; Nakhla, G.; Wan, W.; Wong, K. Effect of the metal oxide particle distributions on modified PES membranes characteristics and performance. J. Membr. Sci. 2010, 361, 213-222. [CrossRef]

91. Csetneki, I.; Filipcsei, G.; Zrínyi, M. Smart nanocomposite polymermembranes with on/off switching control. Macromolecules 2006, 39, 1939-1942. [CrossRef]

92. Daraei, P.; Madaeni, S.S.; Ghaemi, N.; Salehi, E.; Khadivi, M.A.; Moradian, R.; Astinchap, B. Novel polyethersulfone nanocomposite membrane prepared by $\mathrm{PANI} / \mathrm{Fe}_{3} \mathrm{O}_{4}$ nanoparticles with enhanced performance for $\mathrm{Cu}(\mathrm{II})$ removal from water. J. Membr. Sci. 2012, 415-416, 250-259. [CrossRef]

93. Gholami, A.; Moghadassi, A.R.; Hosseini, S.M.; Shabani, S.; Gholami, F. Preparation and characterization of polyvinylchloride based nanocomposite nanofiltration-membrane modified by iron oxide nanoparticles for lead removal from water. J. Ind. Eng. Chem. 2014, 20, 1517-1522. [CrossRef]

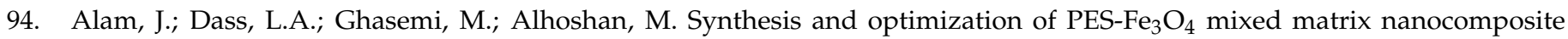
membrane: Application studies in water purification. Polym. Compos. 2013, 34, 1870-1877. [CrossRef]

95. Daraei, P.; Madaeni, S.S.; Ghaemi, N.; Khadivi, M.A.; Astinchap, B.; Moradian, R. Fouling resistant mixed matrix polyethersulfone membranes blended with magnetic nanoparticles: Study of magnetic field induced casting. Sep. Purif. Tech. 2013, 109, 111-121. [CrossRef]

96. María Arsuaga, J.; Sotto, A.; del Rosario, G.; Martínez, A.; Molina, S.; Teli, S.B.; de Abajo, J. Influence of the type, size, and distribution of metal oxide particles on the properties of nanocomposite ultrafiltration membranes. J. Membr. Sci. 2013, 428, 131-141. [CrossRef]

97. Zhao, S.; Wang, P.; Wang, C.; Sun, X.; Zhang, L. Thermostable PPESK/ $\mathrm{TiO}_{2}$ nanocomposite ultrafiltration membrane for high temperature condensed water treatment. Desalination 2012, 299, 35-43. [CrossRef]

98. Teli, S.B.; Molina, S.; Sotto, A.; Calvo, E.G.; De Abajo, J. Fouling resistant polysulfone-PANI/TiO 2 ultrafiltration nanocomposite membranes. Ind. Eng. Chem. Res. 2013, 52, 9470-9479. [CrossRef]

99. Abedini, R.; Mousavi, S.M.; Aminzadeh, R. Effect of sonochemical synthesized $\mathrm{TiO}_{2}$ nanoparticles and coagulation bath temperature on morphology, thermal stability and pure water flux of asymmetric cellulose acetate nanocomposite membranes prepared via phase inversion method. Chem. Ind. Chem. Eng. Q. 2012, 18, 385-398. [CrossRef]

100. Rajaeian, B.; Rahimpour, A.; Tade, M.O.; Liu, S. Fabrication and characterization of polyamide thin film nanocomposite (TFN) nanofiltration membrane impregnated with $\mathrm{TiO}_{2}$ nanoparticles. Desalination 2013, 313, 176-188. [CrossRef] 
101. Ghanbari, M.; Emadzadeh, D.; Lau, W.J.; Lai, S.O.; Matsuura, T.; Ismail, A.F. Synthesis and characterization of novel thin film nanocomposite TFN) membranes embedded with halloysite nanotubes (HNTs) for water deslination. Desalination 2015, 358, 33-41. [CrossRef]

102. Emadzadeh, D.; Ghanbari, M.; Lau, W.J.; Rahbari-Sisakht, M.; Matsuura, T.; Ismail, A.F.; Kruczek, B. Solvothermal synthesis of nanoporous $\mathrm{TiO}_{2}$ : The impact on thin-film composite membranes for engineered osmosis application. Nanotechnology 2016, 27, 345702. [CrossRef]

103. Niksefat, N.; Jahanshahi, M.; Rahimpour, A. The effect of $\mathrm{SiO}_{2}$ nanoparticles on morphology and performance of thin film composite membranes for forward osmosis application. Desalination 2014, 343, 140-146. [CrossRef]

104. Ding, W.; Li, Y.; Bao, M.; Zhang, J.; Zhang, C.; Lu, J. Highly permeable and stable forward osmosis (FO) membrane based on the incorporation of $\mathrm{Al}_{2} \mathrm{O}_{3}$ nanoparticles into both substrate and polyamide active layer. RSC Adv. 2017, 7, 40331. [CrossRef]

105. Wu, H.; Tang, B.; Wu, P. Optimizing polyamide thin film composite membrane covalently bonded with modified mesoporous silica nanoparticles. J. Membr. Sci. 2013, 428, 341-348. [CrossRef]

106. Zhang, M.; Ma, W.; Cui, J.; Wu, S.; Han, J.; Zou, Y.; Huang, C. Hydrothermal synthesized UV-resistance and transparent coating composited superoleophilic electrospun membrane for high efficiency oily wastewater treatment. J. Hazard. Mater. 2020, 383, 121152. [CrossRef]

107. Daraei, P.; Madaeni, S.S.; Salehi, E.; Ghaemi, N.; Ghari, H.S.; Khadivi, M.A.; Rostami, E. Novel thin film composite membrane fabricated by mixed matrix nanoclay/chitosan on PVDF microfiltration support: Preparation, characterization and performance in dye removal. J. Membr. Sci. 2013, 436, 97-108. [CrossRef]

108. Chen, H.; Zheng, S.; Meng, L.; Chen, G.; Luo, X.; Huang, M. Comparison of novel functionalized nanofiber forward osmosis membranes for application in antibacterial activity and TRGs rejection. J. Hazard. Mater. 2020, 392, 12250. [CrossRef]

109. Li, J.; Yuan, S.; Zhu, J.; Bruggen, B.V. High-flux antibacterial composite membranes via polydopamine-assisted PEI-TiO $2 / \mathrm{Ag}$ modification for dye removal. Chem. Eng. J. 2019, 373, 275-284. [CrossRef]

110. Peng, Y.; Yu, Z.; Li, F.; Chen, Q.; Yin, D.; Min, X. A novel reduced graphene oxide-based composite membrane prepared via a facile deposition method for multifunctional applications: Oil/water separation and cationic dyes removal. Sep. Purif. Tech. 2018, 200, 130-140. [CrossRef]

111. Yu, Z.; Min, X.; Li, F.; Yin, D.; Peng, Y.; Zeng, G. A mussel-inspired method to fabricate a novel reduced graphene oxide/ $\mathrm{Bi}_{12} \mathrm{O}_{17} \mathrm{Cl}_{2}$ composites membrane for catalytic degradation and oil/water separation. Polym. Adv. Tech. 2019, 30, 101-109. [CrossRef]

112. Zhang, P.; Gong, J.-L.; Zeng, G.-M.; Song, B.; Cao, W.; Liu, H.-Y.; Huan, S.-Y.; Peng, P. Novel "loose" GO/MoS 2 composites membranes with enhanced permeability for effective salts and dyes rejection at low pressure. J. Membr. Sci. 2019, 574, 112-123. [CrossRef]

113. Zhao, G.; Zou, J.; Chen, X.; Zhang, T.; Yu, J.; Zhou, S.; Li, C.; Jiao, F. Integration of microfiltration and visible-light-driven photocatalysis on a $\mathrm{ZnWO}_{4}$ nanoparticle/nickel-aluminum-layered double hydroxide membrane for enhanced water purification. Ind. Eng. Chem. Res. 2020, 59, 6479-6487. [CrossRef]

114. Xu, Y.; Huang, H.; Ying, G.; Zhang, J.; Wu, Y.; Wu, S.; Yang, Y. Flexible, fouling-resistant and self-cleaning $\mathrm{Ti}_{3} \mathrm{C}_{2} \mathrm{~T}_{\mathrm{x}}-\mathrm{derivated}$ hydrophilic nanofiltration membrane for highly efficient rejection of organic molecules from wastewater. J. Mater. Res. Tech. 2020, 9, 11675-11686. [CrossRef]

115. Amoli-Diva, M.; Irani, E.; Pourghazi, K. Photocatalytic filtration reactors equipped with bi-plasmonic nanocomposite/poly acrylic acid-modified polyamide membranes for industrial wastewater treatment. Sep. Purif. Tech. 2020, 236, 116257. [CrossRef]

116. Guan, J.; Fan, L.; Liu, Y.-N.; Shi, B.; Yuan, J.; Zhang, R.; You, X.; He, M.; Su, Y.; Jiang, Z. Incorporating arginine-Fe ${ }^{\mathrm{III}}$ complex into polyamide membranes for enhanced water performance and antifouling performance. J. Membr. Sci. 2020, 602, 117980. [CrossRef]

117. Song, X.; Wang, L.; Tang, C.Y.; Wang, Z.; Gao, C. Fabrication of carbon nanotubes incorporated double-skinned thin film nanocomposite membranes for enhanced separation performance and antifouling capability in forward osmosis process. Desalination 2015, 369, 1-9. [CrossRef]

118. Amini, M.; Jahanshahi, M.; Rahimpour, A. Synthesis of novel thin film nanocomposite (TFN) forward osmosis membranes using functionalized multi-walled carbon nanotubes. J. Membr. Sci. 2013, 435, 233-241. [CrossRef]

119. Zhao, H.; Qiu, S.; Wu, L.; Zhang, L.; Chen, H.; Gao, C. Improving the performance of polyamide reverse osmosis membrane by incorporation of modified multi-walled carbon nanotubes. J. Membr. Sci. 2014, 450, 249-256. [CrossRef]

120. Shen, L.; Xiong, S.; Wang, Y. Graphene oxide incorporated thin-film composite membranes for forward osmosis applications. Chem. Eng. Sci. 2016, 143, 194-205. [CrossRef]

121. Wu, X.; Field, R.W.; Wu, J.J.; Zhang, K. Polyvinylpyrrolidone modified graphene oxide as a modifier for thin film composite forward osmosis membranes. J. Membr. Sci. 2017, 540, 251-260. [CrossRef]

122. Rastgar, M.; Shakeri, A.; Bozong, A.; Salehi, H.; Saadattalab, V. Highly-efficient forward osmosis membrane tailored by magnetically responsive graphene oxide $/ \mathrm{Fe}_{3} \mathrm{O}_{4}$ nanohybrid. Appl. Surf. Sci. 2018, 441, 923-935. [CrossRef]

123. Eslah, S.S.; Shokrollahzadeh, S.; Jazani, O.M.; Samimi, A. Fprward osmosis water desalination: Fabrication of graphene oxidepolyamide/polysulfone thin-film nanocomposite membrane with high water flux and low reverse salt diffusion. Sep. Sci. Tech. 2018, 53, 573-583. [CrossRef]

124. Yin, J.; Zhu, G.; Deng, B. Graphene oxide (GO) enhanced polyamide (PA) thin-film nanocomposite (TFN) membrane for water purification. Desalination 2016, 379, 93-101. [CrossRef] 
125. Majooni, Y.; Mortaheb, H.R.; Dizaji, A.K. Enhancement in pervaporative performance of PDMS membrane for separation of styrene from wastewater by hybridizing with reduced graphene oxide. J. Environ. Manag. 2020, 261, 110189. [CrossRef] [PubMed]

126. Seyedpour, S.F.; Rahimpour, A.; Shamsabadi, A.A.; Soroush, M. Improved performance and antifouling properties of thin-film composite polyamide membranes modified with nano-sized bactericidal graphene quantum dots for forward osmosis. Chem. Eng. Res. Des. 2018, 139, 321-334. [CrossRef]

127. Goh, P.S.; Ismail, A.F.; Ng, B.C. Carbon nanotubes for desalination: Performance evaluation and current hurdles. Desalination 2013, 308, 2-14. [CrossRef]

128. Goh, K.; Karahan, H.E.; Wei, L.; Bae, T.-H.; Fane, A.G.; Wang, R.; Chen, Y. Carbon nanomaterials for advancing separation membranes: A strategic perspective. Carbon 2016, 109, 694-710. [CrossRef]

129. Mattia, D.; Lee, K.P.; Calabro, F. Water permeation in carbon nanotube membranes. Curr. Opin. Chem. Eng. 2014, 4, 32-37. [CrossRef]

130. Das, R.; Hamid, S.B.A.; Ali, M.E.; Ismail, A.F.; Annuar, M.S.M.; Ramakrishna, S. Multifunctional carbon nanotubes in water treatment: The present, past and future. Desalination 2014, 354, 160-179. [CrossRef]

131. Das, R.; Ali, M.E.; Hamid, S.B.A.; Ramakrishna, S.; Chowdhury, Z.Z. Carbon nanotube membranes for water purification: A bright future in water desalination. Desalination 2014, 336, 97-109. [CrossRef]

132. Cony, B. Designing carbon nanotube membranes for efficient water desalination. J. Phys. Chem. B 2008, 112, 1427-1434.

133. Chen, C.; Yang, Q.-H.; Yang, Y.; Lv, W.; Wen, Y.; Hou, P.-X.; Wang, M.; Cheng, H.-M. Self-assembled free-standing graphite oxide membrane. Adv. Mater. 2009, 21, 3007-3011. [CrossRef]

134. Backes, C.; Hauke, F.; Hirsch, A. The potential of perylene bisimide derivatives for the solubilization of carbon nanotubes and graphene. Adv. Mater. 2011, 23, 2588-2601. [CrossRef] [PubMed]

135. Li, F.; Bao, Y.; Chai, J.; Zhang, Q.; Han, D.; Niu, L. Synthesis and application of widely soluble graphene sheets. Langmuir 2010, 26, 12314-12320. [CrossRef]

136. Hung, W.-S.; An, Q.-F.; De Guzman, M.; Lin, H.-Y.; Huang, S.-H.; Liu, W.-R.; Hu, C.-C.; Lee, K.-R.; Lai, J.-Y. Pressure-assisted selfassembly technique for fabricating composite membranes consisting of highly ordered selective laminate layers of amphiphilic graphene oxide. Carbon 2014, 68, 670-677. [CrossRef]

137. Hegab, H.M.; Zou, L. Graphene oxide-assisted membranes: Fabrication and potential applications in desalination and water purification. J. Membr. Sci. 2015, 484, 95-106. [CrossRef]

138. Faria, A.F.; Liu, C.; Xie, M.; Perreault, F.; Nghiem, L.D.; Ma, J.; Elimelech, M. Thin-film composite forward osmosis membranes functionalized with graphene oxide-silver nanocomposites for biofouling control. J. Membr. Sci. 2017, 525, 146-156. [CrossRef]

139. Inurria, A.; Cay-Durgun, P.; Rice, D.; Zhang, H.; Seo, D.-K.; Ling, M.L.; Perreault, F. Polyimide thin-film nanocomposite membrane with graphene oxide nanosheets: Balancing membrane performance and fouling propensity. Desalination 2018, 451, 139-147. [CrossRef]

140. Perreault, F.; Jaramillo, H.; Xie, M.; Ude, M.; Nghiem, L.D.; Elimelech, M. Biofouling mitigation in forward osmosis using graphene oxide functionalized thin-film composite membranes. Environ. Sci. Tech. 2016, 50, 5840-5848. [CrossRef]

141. Marchetti, P.; Solomon, M.F.J.; Szekely, G.; Livingston, A.G. Molecular separation with organic solvent nanofiltration: A critical review. Chem. Rev. 2014, 114, 10735-10806. [CrossRef] [PubMed]

142. Matsumoto, Y.; Sudoh, M.; Suzuki, Y. Preparation of composite UF membranes of sulfonated polysulfone coated on ceramics. J. Membr. Sci. 1999, 158, 55-62. [CrossRef]

143. Peters, T.A.; Poeth, C.H.S.; Benes, N.E.; Bujis, H.C.W.M.; Vercauteren, F.F.; Keurentjes, J.T.F. Ceramic-supported thin PVA pervaporation membranes combining high flux and high selectivity; contradicting the flux-selectivity paradigm. J. Membr. Sci. 2006, 276, 42-50. [CrossRef]

144. Yoshida, W.; Cohen, Y. Removal of methyl tert-butyl ether from water by pervaporation using ceramic-supported polymer membranes. J. Membr. Sci. 2004, 229, 27-32. [CrossRef]

145. Xiangli, F.; Chen, Y.; Jin, W.; Xu, N. Polydimethylsiloxane (PDMS)/ceramic composite membrane with high flux for pervaporation of ethanol-water mixtures. Ind. Eng. Chem. Res. 2007, 46, 2224-2230. [CrossRef]

146. Zhu, Y.; Xia, S.; Liu, G.; Jin, W. Preparation of ceramic-supported poly(vinyl alcohol)-chitosan composite membranes and their applications in pervaporation dehydration of organic/water mixtures. J. Membr. Sci. 2010, 349, 341-348. [CrossRef]

147. Chen, Y.; Xiangli, F.; Jin, W.; Xu, N. Organic-inorganic composite pervaporation membranes prepared by self-assembly of polyelectrolyte multilayers on microporous ceramic supports. J. Membr. Sci. 2007, 302, 78-86. [CrossRef]

148. Randon, J.; Paterson, R. Preliminary studies on the potential for gas separation by mesoporous ceramic oxide membranes surface modified by alkyl phosphonic acids. J. Membr. Sci. 1997, 134, 219-223. [CrossRef]

149. Lu, M.; Hu, M.Z. Novel porous ceramic tube-supported polymer layer membranes for acetic acid/water separation by pervaporation dewatering. Sep. Purif. Tech. 2020, 236, 116312. [CrossRef]

150. Chen, G.; Zhu, H.; Hang, Y.; Liu, Q.; Liu, G.; Jin, W. Simultaneously enhancing interfacial adhesion and pervaporation separation performance of PDMS/ceramic composite membrane via a facile substrate surface grafting approach. AIChE J. 2019, 65, 16773. [CrossRef]

151. Xia, L.; Ren, J.; Weyd, M.; McCutcheon, J.R. Ceramic-supported thin film composite membrane for organic solvent nanofiltration. J. Membr. Sci. 2018, 563, 857-863. [CrossRef] 
152. Chong, J.Y.; Wang, R. From micro to nano: Polyamide thin film on microfiltration ceramic tubular membranes for nanofiltration. J. Membr. Sci. 2019, 587, 117161. [CrossRef]

153. Xu, R.; Liu, G.; Dong, X.; Jin, W. Pervaporation separation of n-octane/thiophene mixtures using polydimethylsiloxane/ceramic composite membranes. Desalination 2010, 258, 106-111. [CrossRef]

154. Amirilargani, M.; Yokota, G.N.; Vermeji, G.H.; Merlet, R.B.; Delen, G.; Mandemaker, L.D.B.; Weckhuysen, B.M.; Winnubst, L.; Nijmeijer, A.; de Smet, L.C.P.M.; et al. Melamine-based microporous organic framework thin films on an alumina membrane for high-flux organic solvent nanofiltration. ChemSusChem 2020, 13, 136-140. [CrossRef] [PubMed]

155. Menne, D.; Uzum, C.; Koppelmann, A.; Wong, J.E.; van Foeken, C.; Borre, F.; Dahne, L.; Laakso, T.; Pihlajamaki, A.; Wessling, M. Regenerable polymer/ceramic hybrid nanofiltration membrane based on polyelectrolyte assembly by layer-by-layer technique. $J$. Membr. Sci. 2016, 520, 924-932. [CrossRef]

156. Maaskant, E.; de Wit, P.; Benes, N.E. Direct interfacial polymerization onto thin ceramic hollow fibers. J. Membr. Sci. 2018, 550, 296-301. [CrossRef]

157. Amirilargani, M.; Merlet, R.B.; Nijmeijer, A.; Winnubst, L.; de Smet, L.C.P.M.; Sudholter, E.J.R. Poly (maleic anhydride-alt-1alkenes) directly grafted to $\gamma$-alumina for high-performance organic solvent nanofiltration membranes. J. Membr. Sci. 2018, 564, 259-266. [CrossRef]

158. Wang, J.-W.; Li, X.-Z.; Fan, M.; Gu, J.-Q.; Hao, L.-Y.; Xu, X.; Chen, C.-S.; Wang, C.-M.; Hao, Y.-Z.; Agathopoulos, S. Porous $\beta$-sialon planar membrane with a robust polymer-derived hydrophobic ceramic surface. J. Membr. Sci. 2017, 535, 63-69. [CrossRef]

159. Liu, G.; Wei, W.; Wu, H.; Dong, X.; Jiang, M.; Jin, W. Pervaporation performance of PDMS/ceramic composite membrane in acetone butanol ethanol (ABE) fermentation-PV coupled process. J. Membr. Sci. 2011, 373, 121-129. [CrossRef]

160. Escorihuela, S.; Tena, A.; Shishatskiy, S.; Escolastico, S.; Brinkmann, T.; Serra, J.M.; Abetz, V. Gas separation properties of polyimide thin films on ceramic supports for high temperature application. Membranes 2018, 8, 16. [CrossRef]

161. Faibish, R.S.; Cohen, Y. Fouling-resistant ceramic-supported polymer membranes for ultrafiltration of oil-in-water microemulsions. J. Membr. Sci. 2001, 185, 129-143. [CrossRef]

162. Jana, S.; Saikia, A.; Purkait, M.K.; Mohanty, K. Chitosan based ceramic ultrafiltration membrane: Preparation, characterization and application to remove $\mathrm{Hg}$ (II) and As (III) using polymer enhanced ultrafiltration. Chem. Eng. J. 2011, 170, 209-219. [CrossRef]

163. Wei, W.; Xia, S.; Liu, G.; Dong, X.; Jin, W.; Xu, N. Effects of polydimethylsiloxane (PDMS) molecular weight on performance of PDMS/ceramic composite membranes. J. Membr. Sci. 2011, 375, 334-344. [CrossRef]

164. Guerra, K.; Pellegrino, J. Development of a Techno-Economic model to compare ceramic and polymeric membranes. Sep. Sci. Tech. 2013, 48, 51-65. [CrossRef]

165. Arkell, A.; Olsson, J.; Wallberg, O. Process performance in lignin separation from softwood black liquor by membrane filtration. Chem. Eng. Res. Des. 2014, 92, 1792-1800. [CrossRef]

166. Zhang, R.; Liu, Y.; He, M.; Su, Y.; Zhao, X.; Elimelech, M.; Jiang, Z. Antifouling membranes for sustainable water purification: Strategies and mechanisms. Chem. Soc. Rev. 2016, 45, 5888-5924. [CrossRef] [PubMed]

167. Jiang, Z.-Y.; Liu, H.-L.; Ahmed, S.A.; Hanif, S.; Ren, S.-B.; Xu, J.-J.; Chen, H.-Y.; Xia, X.-H.; Wang, K. Insight into ion transfer through the sub-nanometer channels in zeolitic imidazolate frameworks. Angew. Chem. Int. Ed. 2017, 56, 4767-4771. [CrossRef]

168. Benkhaya, S.; Achiou, B.; Ouammou, M.; Bennazha, J.; Younssi, S.A.; M'rabet, S.; Harfu, A.E. Preparation of low-cost composite membrane made of polysulfone/polyetherimide ultrafiltration layer and ceramic possolan support for dyes removal. Mater. Today Comm. 2019, 19, 212-219. [CrossRef]

169. Lee, S.J.; Han, S.W.; Yoon, M.; Kim, K. Adsorption characteristics of 4-dimethylaminobenzoic acid on silver and titania: Diffuse reflectance infrared Fourier transform spectroscopy. Vib. Spectrosc. 2000, 24, 265-275. [CrossRef]

170. Luo, M.-L.; Zhao, J.-Q.; Tang, W.; Pu, C.-S. Hydrophilic modification of poly(ether sulfone) ultrafiltration membrane surface by self-assembly of $\mathrm{TiO}_{2}$ nanoparticles. Appl. Surf. Sci. 2005, 249, 76-84. [CrossRef]

171. Wang, X.-M.; Li, X.-Y.; Shih, K. In situ embedment and growth of anhydrous and hydrated aluminum oxide particles on polyvinylidene fluoride (PVDF) membranes. J. Membr. Sci. 2011, 368, 134-143. [CrossRef]

172. Gohari, R.J.; Halakoo, E.; Nazri, N.A.M.; Lau, W.J.; Matsuura, T.; Ismail, A.F. Improving performance and antifouling capability of PES UF membranes via blending with highly hydrophilic hydrous manganese dioxide nanoparticles. Desalination 2014, 335, 87-95. [CrossRef]

173. Yogarathinam, L.T.; Gangasalam, A.; Ismail, A.F.; Arumugam, S.; Narayanan, A. Concentration of whey protein from cheese whey effluent using ultrafiltration by combination of hydrophilic metal oxides and hydrophobic polymer. J. Chem. Tech. Biotech. 2018, 93, 2576-2591. [CrossRef]

174. Wu, H.; Zheng, B.; Zheng, X.; Wang, J.; Yuan, W.; Jiang, Z. Surface-modified Y zeolite-filled chitosan membrane for direct methanol fuel cell. J. Power Sources 2007, 173, 842. [CrossRef]

175. Sun, H.; Lu, L.; Chen, X.; Jiang, Z. Surface-modified zeolite-filled chitosan membranes for pervaporation dehydration of ethanol. Appl. Surf. Sci. 2008, 254, 5367-5374. [CrossRef]

176. Ayyaru, S.; Ahn, Y.-H. Fabrication and separation performance of polyethersulfone/sulfonated $\mathrm{TiO}_{2}\left(\mathrm{PES}-\mathrm{STiO}_{2}\right)$ ultrafiltration membranes for fouling mitigation. J. Ind. Eng. Chem. 2018, 67, 199-209. [CrossRef]

177. Bae, T.-H.; Liu, J.; Lee, J.S.; Koros, W.J.; Jones, C.W.; Nair, S. Facile high-yield solvothermal deposition of inorganic nanostructures on zeolite crystals for mixed matrix membrane fabrication. J. Am. Chem. Soc. 2009, 131, 14662-14663. [CrossRef] 
178. Zhang, L.-P.; Liu, Z.; Faraj, Y.; Zhao, Y.; Zhuang, R.; Xie, R.; Ju, X.-J.; Wang, W.; Chu, L.-Y. High-flux efficient catalytic membranes incorporated with iron-based Fenton-like catalysts for degradation of organic pollutants. J. Membr. Sci. 2019, 573, 493-503. [CrossRef]

179. Zakeritabar, S.F.; Jahanshahi, M.; Peyravi, M. Photocatalytic behavior of induced membrane by $\mathrm{ZrO}_{2}-\mathrm{SnO}_{2}$ nanocomposite for pharmaceutical wastewater treatment. Catal. Lett. 2018, 148, 882-893. [CrossRef]

180. Liu, W.; Zhang, Y.; Zhang, L.; Guo, J.; Wei, J. Polysulfone ultrafiltration membrane promoted by brownmillerite $\mathrm{SrCu}_{\mathrm{x}} \mathrm{Co}_{1-\mathrm{x}} \mathrm{O}_{3-\lambda}{ }^{-}$ deposited MCM-41 for industrial wastewater decontamination: Catalytic oxidation and antifouling properties. Ind. Eng. Chem. Res. 2020, 59, 7805-7815. [CrossRef]

181. Zeng, G.; He, Y.; Xu, Z.; Zhan, Y.; Ma, L.; Zhang, L. Preparation and characterization of a novel PVDF ultrafiltration membrane by blending with $\mathrm{TiO}_{2}-\mathrm{HNTs}$ nanocomposites. Appl. Surf. Sci. 2016, 271, 624-632. [CrossRef]

182. Liu, Y.; Gao, R.; Shen, G.; Li, Y.; Li, Y.; Gou, J.; Cheng, X. Construction of CuO@CuS/PVDF composite membrane and its superiority for degradation of antibiotics by activation of persulfate. Chem. Eng. J. 2021, 405, 126990. [CrossRef]

183. Zhang, G.; Lu, S.; Zhang, L.; Meng, Q.; Shen, C.; Zhang, J. Novel polysulfone hybrid ultrafiltration membrane prepared with $\mathrm{TiO}_{2}$-g-HEMA and its antifouling characteristics. J. Membr. Sci. 2013, 436, 163-173. [CrossRef]

184. Zhi, S.-H.; Xu, J.; Deng, R.; Wang, L.-S.; Xu, Z.-K. Poly(vinylidene fluoride) ultrafiltration membranes containing hybrid silica nanoparticles: Preparation, characterization and performance. Polymer 2014, 55, 1333-1340. [CrossRef]

185. Zhao, X.; Ma, J.; Wang, Z.; Wen, G.; Jiang, J.; Shi, F.; Sheng, L. Hyperbranched-polymer functionalized multi-walled carbon nanotubes for poly(vinylidene fluoride) membranes: From dispersion to blended fouling-control membrane. Desalination 2012, 303, 29-38. [CrossRef]

186. Ilyas, H.; Shawuti, S.; Siddiq, M.; Niazi, J.H.; Qureshi, A. PEG functionalized graphene oxide-silver nano-additive for enhanced hydrophilicity, permeability and fouling resistance properties of PVDF-co-HFP membranes. Colloids Surf. A Physicochem. Eng. Asp. 2019, 579, 123646. [CrossRef]

187. Etemadi, H.; Yegani, R.; Seyfollahi, M.; Rabiee, M. Synthesis, characterization, and antifouling properties of cecllulose acetate/polyethylene glycol-grafted nanodiamond nanocomposite membranes for humic acid removal from contaminated water. Iran. Polym. J. 2018, 27, 381-393. [CrossRef]

188. Khodadousti, S.; Ashtiani, F.Z.; Karimi, M.; Fouladitajar, A. Preparation and characterization of novel PES-(SiO $2-\mathrm{g}-\mathrm{PMAA}_{\mathrm{P}}$ membranes with antifouling and hydrophilic properties for separation of oil-in-water emulsions. Polym. Adv. Tech. 2019, 30, 2221-2232. [CrossRef]

189. Wang, H.; Lu, X.; Lu, X.; Wang, Z.; Ma, J.; Wang, P. Improved surface hydrophilicity and antifouling property of polysulfone ultrafiltration membrane with poly(ethylene glycol) methyl ether methacrylate grafted graphene oxide nanofillers. Appl. Surf. Sci. 2017, 425, 603-613. [CrossRef]

190. Liang, X.; Wang, P.; Wang, J.; Zhang, Y.; Wu, W.; Liu, J.; Bruggen, B. Zwitterionic functionalized MoS 2 nanosheets for a novel composite membrane with effective salt/dye separation performance. J. Membr. Sci. 2019, 573, 270-279. [CrossRef]

191. Su, Y.-H.; Liu, Y.-L.; Sun, Y.-M.; Lai, J.-Y.; Wang, D.-M.; Gao, Y.; Liu, B.; Guiver, M.D. Proton exchange membranes modified with sulfonated silica nanoparticles for direct methanol fuel cells. J. Membr. Sci. 2007, 296, 21-28. [CrossRef]

192. Gosalawit, R.; Chirachanchai, S.; Shishatskiy, S.; Nunes, S.P. Sulfonated montmorillonite/sulfonated poly(ether ether ketone)(SMMT/SPEEK) nanocomposite membrane for direct methanol fuel cells (DMFCs). J. Membr. Sci. 2008, 323, 337-346. [CrossRef]

193. Li, X.; Li, J.; Bruggen, B.; Sun, X.; Shen, J.; Han, W.; Wang, L. Fouling behavior of polyethersulfone ultrafiltration membranes functionalized with sol-gel formed $\mathrm{ZnO}$ nanoparticles. RSC Adv. 2015, 5, 50711-50719. [CrossRef]

194. Chen, W.; Su, Y.; Zhang, L.; Shi, Q.; Peng, J.; Jiang, Z. In situ generated silica nanoparticles as pore-forming agent for enhanced permeability of cellulose acetate membranes. J. Membr. Sci. 2010, 348, 75-83. [CrossRef]

195. Lv, Y.; Yang, H.-C.; Liang, H.-Q.; Wan, L.-S.; Xu, Z.-K. Novel nanofiltration membrane with ultrathin zirconia film as selective layer. J. Membr. Sci. 2016, 500, 265-271. [CrossRef]

196. Tang, L.; Livi, K.J.T.; Chen, K.L. Polysulfone membranes modified with bioinspired polydopamine and silver nanoparticles formed in situ to mitigate biofouling. Environ. Sci. Tech. Lett. 2015, 2, 59-65. [CrossRef]

197. Huang, L.; Zhao, S.; Wang, Z.; Wu, J.; Wang, J.; Wang, S. In situ immobilization of silver nanoparticles for improving permeability, antifouling and anti-bacterial properties of ultrafiltration membrane. J. Membr. Sci. 2016, 499, 269-281. [CrossRef]

198. Zhang, W.; Hu, B.; Wang, Z.; Li, B. Fabrication of omniphobic PVDF composite membrane with dual-scale hierarchical structure via chemical bonding for robust membrane distillation. J. Membr. Sci. 2021, 622, 119038. [CrossRef]

199. Derami, H.G.; Gupta, P.; Gupta, R.; Rathi, P.; Morrissey, J.J.; Singamaneni, S. Palladium nanoparticle-decorated mesoporous polydopamine/bacterial nanocellulose as a catalytically active universal dye removal ultrafiltration membrane. ACS Appl. Nano Mater. 2020, 3, 5437-5448. [CrossRef]

200. Soyekwo, F.; Liu, C.; Wen, H.; Hu, Y. Construction of an electroneutral zinc incorporated polymer network nanocomposite membrane with enhanced selectivity for salt/dye separation. Chem. Eng. J. 2020, 380, 122560. [CrossRef]

201. Zhou, Q.; Xu, S.; Zhu, C.; Cao, B.; Kausar, F.; Xu, A.; Yuan, W.Z.; Zhang, Y. Towards high-performance hybrid hydrophilic membranes: Chemical anchoring of hydroxyl-rich nanoparticles on PVDF membranes via a silane coupling agent. J. Mater. Sci. 2017, 52, 11737-11748. [CrossRef] 
202. Boo, C.; Lee, J.; Elimelech, M. Omniphobic polyvinylidene fluoride (PVDF) membrane for desalination of shale gas produced water by membrane distillation. Environ. Sci. Technol. 2016, 50, 12275-12282. [CrossRef]

203. Pan, Y.; Yu, Z.; Shi, H.; Chen, Q.; Zeng, G.; Di, H.; Ren, X.; He, Y. A novel antifouling and antibacterial surface-functionalized PVDF ultrafiltration membrane via binding $\mathrm{Ag} / \mathrm{SiO}_{2}$ nanocomposites. J. Chem. Technol. Biotechnol. 2017, 92, 562-572. [CrossRef]

204. Lu, T.; Xu, X.; Liu, X.; Sun, T. Super hydrophilic PVDF based composite membrane for efficient separation of tetracycline. Chem. Eng. J. 2017, 308, 151-159. [CrossRef]

205. Jaleh, B.; Etivand, E.S.; Mohazzab, B.F.; Nasrollahzadeh, M.; Varma, R.S. Improving wettability: Deposition of TiO 2 nanoparticles on the $\mathrm{O}_{2}$ plasma activated polypropylene membrane. Int. J. Mol. Sci. 2019, 20, 3309. [CrossRef] [PubMed]

206. Chen, X.; Huang, G.; An, C.; Feng, R.; Yao, Y.; Zhao, S.; Huang, C.; Wu, Y. Plasma-induced poly(acrylic acid)-TiO 2 coated polyvinylidene fluoride membrane for produced water treatment: Synchrotron X-ray, optimization, and insight studies. J. Clean. Prod. 2019, 227, 772-783. [CrossRef]

207. Liang, S.; Kang, Y.; Tiraferri, A.; Giannelis, E.P.; Huang, X.; Elimelech, M. Highly hydrophilic polyvinylidene fluoride (PVDF) ultrafiltration membranes via postfabrication grafting of surface-tailored silica nanoparticles. ACS Appl. Mater. Interfaces 2013, 5, 6694-6703. [CrossRef] [PubMed]

208. Chen, P.-C.; Xu, Z.-K. Mineral-coated polymer membranes with superhydrophilicity and underwater superoleophobic for effective oil/water separation. Sci. Rep. 2013, 3, 2776. [CrossRef]

209. Zhang, C.; Yang, H.C.; Wan, L.S.; Liang, H.Q.; Li, H.; Xu, Z.K. Polydopamine-coated porous substrates as a platform for mineralized $\beta$-FeOOH nanorods with photocatalysis under sunlight. ACS Appl. Mater. Interfaces 2015, 7, 11567-11574. [CrossRef]

210. Zhi, S.-H.; Wan, L.-S.; Xu, Z.-K. Poly(vinylidene fluoride)/poly(acrylic acid)/calcium carbonate composite membranes via mineralization. J. Membr. Sci. 2014, 454, 144-154. [CrossRef]

211. Chen, P.-C.; Wan, L.-S.; Xu, Z.-K. Bio-inspired $\mathrm{CaCO}_{3}$ coating for superhydrophilic hybrid mambranes with high water permeability. J. Mater. Chem. 2012, 22, 22727-22733. [CrossRef]

212. Yang, H.C.; Chen, Y.F.; Ye, C.; Jin, Y.N.; Li, H.; Xu, Z.K. Polymer membrane with a mineral coating for enhanced curling resistance and surface wettability. Chem. Commun. 2015, 51, 12779-12782. [CrossRef]

213. Yang, H.C.; Pi, J.K.; Liao, K.J.; Huang, H.; Wu, Q.Y.; Huang, H.J.; Xu, Z.K. Silica-decorated polypropylene microfiltration membranes with a mussel-inspired intermediate layer for oil-in-water emulsion separation. ACS Appl. Mater. Interfaces 2014, 6, 12566-12572. [CrossRef]

214. Yang, H.-C.; Liao, K.-J.; Huang, H.; Wu, Q.-Y.; Wan, L.-S.; Xu, Z.K. Mussel-inspired modification of a polymer membrane for ultra-high water permeability and oil-in-water emulsion separation. J. Mater. Chem. A 2014, 2, 10225-10230. [CrossRef]

215. Pi, J.K.; Wu, G.P.; Yang, H.C.; Arges, C.G.; Xu, Z.K. Separators with biomineralized zirconia coatings for enhanced thermo- and electro-performance of lithium-ion batteries. ACS Appl. Mater. Interfaces 2017, 9, 21971-21978. [CrossRef]

216. Cui, J.; Zhou, Z.; Xie, A.; Wang, Q.; Liu, S.; Lang, J.; Li, C.; Yan, Y.; Dai, J. Facile preparation of grass-like structured NiCoLDH/PVDF composite membrane for efficient oil-water emulsion separation. J. Membr. Sci. 2019, 573, 226-233. [CrossRef]

217. Ding, W.; Zhuo, H.; Bao, M.; Li, Y.; Lu, J. Fabrication of organic-inorganic nanofiltration membrane using ordered stacking $\mathrm{SiO}_{2}$ thin film as rejection layer assisted with layer-by-layer method. Chem. Eng. J. 2017, 330, 337-344. [CrossRef]

218. Wongchitphimon, S.; Rongwong, W.; Chuah, C.Y.; Wang, R.; Bae, T.-H. Polymer-fluorinated silica composite hollow fiber membranes for the recovery of biogas dissolved in anaerobic effluent. J. Membr. Sci. 2017, 540, 146-154. [CrossRef]

219. Lin, Y.; Loh, C.H.; Shi, L.; Fan, Y.; Wang, R. Preparation of high-performance $\mathrm{Al}_{2} \mathrm{O}_{3} / \mathrm{PES}$ composite hollow fiber UF membranes via facile in-situ vapor induced hydrolyzation. J. Membr. Sci. 2017, 539, 65-75. [CrossRef]

220. Qin, A.; Li, X.; Zhao, X.; Liu, D.; He, C. Engineering a highly hydrophilic PVDF membrane via binding $\mathrm{TiO}_{2}$ nanoparticles and a PVA layer onto a membrane surface. ACS Appl. Mater. Interfaces 2015, 7, 8427-8436. [CrossRef] [PubMed]

221. Loh, C.H.; Wang, R. Insight into the role of amphiphilic pluronic block copolymer as pore-forming additive in PVDF membrane formation. J. Membr. Sci. 2013, 446, 492-503. [CrossRef]

222. Yang, H.C.; Waldman, R.Z.; Chen, Z.; Darling, S.B. Atomic layer deposition for membrane interface engineering. Nanoscale 2018, 10, 20505-20513. [CrossRef]

223. Leskela, M.; Ritala, M. Atomic layer deposition chemistry: Recent developments and future challenges. Angew. Chem. Int. Ed. 2003, 42, 5548-5554. [CrossRef] [PubMed]

224. Steven, G.M. Atomic layer deposition: An overview. Chem. Rev. 2010, 1, 111-131.

225. Yang, H.C.; Xie, Y.; Chan, H.; Narayanan, B.; Chen, L.; Waldman, R.Z.; Sankaranarayanan, S.; Elam, J.W.; Darling, S.B. Crude-oilrepellent membranes by atomic layer deposition: Oxide interface engineering. ACS Nano 2018, 12, 8678-8685. [CrossRef]

226. Xu, Q.; Yang, Y.; Yang, J.; Wang, X.; Wang, Z.; Wang, Y. Plasma activation of porous polytetrafluoroethylene membranes for superior hydrophilicity and separation performances via atomic layer deposition of $\mathrm{TiO}_{2}$. J. Membr. Sci. $2013,443,62-68$. [CrossRef]

227. Xu, Q.; Yang, J.; Dai, J.; Yang, Y.; Chen, X.; Wang, Y. Hydrophilization of porous polypropylene membranes by atomic layer deposition of $\mathrm{TiO}_{2}$ for simultaneously improved permeability and selectivity. J. Membr. Sci. 2013, 448, 215-222. [CrossRef]

228. Chen, H.; Kong, L.; Wang, Y. Enhancing the hydrophilicity and water permeability of polypropylene membranes by nitric acid activation and metal oxide deposition. J. Membr. Sci. 2015, 487, 109-116. [CrossRef]

229. Wei, W.; Xia, S.; Liu, G.; Gu, X.; Jin, W.; Xu, N. Interfacial adhesion between polymer separation layer and ceramic support for composite membrane. AIChE J. 2010, 56, 1584-1592. [CrossRef] 
230. Hang, Y.; Liu, G.; Huang, K.; Jin, W. Mechanical properties and interfacial adhesion of composite membranes probed by in-situ nano-indentation/scratch technique. J. Membr. Sci. 2015, 494, 205-215. [CrossRef]

231. Hamm, J.B.S.; Ambrosi, A.; Pollo, L.D.; Marcillo, N.R.; Tessaro, I.G. Thin polymer layer-covered porous alumina tubular membranes prepared via a dip-coating/phase-inversion process. Mater. Chem. Phys. 2021, 265, 124511. [CrossRef]

232. Shi, G.M.; Chung, T.-S. Thin film composite membranes on ceramic for pervaporation dehydration isopropanol. J. Membr. Sci. 2013, 448, 34-43. [CrossRef]

233. Faibish, R.S.; Cohen, Y. Fouling and rejection behavior of ceramic and polymer-modified ceramic membranes for ultrafiltration of oil-in-water emulsions and microemulsions. Colloids Surf. A Physicochem. Eng. Asp. 2001, 191, 27-40. [CrossRef]

234. Wang, X.; Wang, T.; Ma, J.; Liu, H.; Ning, P. Synthesis and characterization of a new hydrophilic boehmite-PVB/PVDF blended membrane supported nano zero-valent iron for removal of Cr(IV). Sep. Purif. Tech. 2018, 205, 74-83. [CrossRef]

235. Lakhotia, S.R.; Mukhopadhyay, M.; Kumari, P. Surface-Modified Nanocomposite Membranes. Sep. Purif. Rev. 2018, 47, 288-305. [CrossRef]

236. Issac, M.N.; Kandasubramanian, B. Review of manufacturing three-dimensional-printed membranes for water treatment. Environ. Sci. Poll. Res. 2020, 27, 36091-36108. [CrossRef] [PubMed]

237. Al-Shimmery, A.; Mazinanni, S.; Ji, J.; Chew, Y.M.J.; Mattia, D. 3D printed composite membranes with enhanced anti-fouling behavior. J. Membr. Sci. 2019, 574, 76-85. [CrossRef]

238. Lyu, Z.; Ng, T.C.A.; Tran-Duc, T.; Lim, G.J.H.; Gu, Q.; Zhang, L.; Zhang, Z.; Ding, J.; Phan-Thien, N.; Wang, J.; et al. 3D-printed surface-patterned ceramic membrane with enhanced performance in crossflow filtration. J. Membr. Sci. 2020, 606, 118138. [CrossRef]

239. Klemm, D.; Heublein, B.; Fink, H.-P.; Bohn, H.A. Cellulose: Fascinating biopolymer and sustainable raw material. Angezw. Chem. Int. Ed. 2005, 44, 3358-3393. [CrossRef]

240. Mohammadi, T.; Saljoughi, E. Effect of production conditions on morphology and permeability of asymmetric cellulose acetate membranes. Desalination 2009, 243, 1-7. [CrossRef] 